\title{
Harmful or useful? A case study of the exotic peregrine earthworm morphospecies Pontoscolex corethrurus
}

\author{
S. Taheri ${ }^{\mathrm{a}, *}$, C. Pelosi ${ }^{\mathrm{b}}$, L. Dupont ${ }^{\mathrm{a}, * *}$ \\ ${ }^{\text {a }}$ Université Paris Est Créteil, Université Pierre et Marie Curie, CNRS, INRA, IRD, Université Paris-Diderot, Institut d'écologie et des Sciences de l'environnement de Paris \\ (iEES-Paris), Créteil, France \\ ${ }^{\mathrm{b}}$ UMR ECOSYS, INRA, AgroParisTech, Université Paris-Saclay, 78026 Versailles, France
}

\begin{abstract}
A B S T R A C T
Exotic peregrine earthworms are often considered to cause environmental harm and to have a negative impact on native species, but, as ecosystem engineers, they enhance soil physical properties. Pontoscolex corethrurus is by far the most studied morphospecies and is also the most widespread in tropical areas. The term of morphospecies is used in this review because $P$. corethrurus may in fact constitute a complex of cryptic species. This earthworm is found in a wide range of habitats, from apparently pristine to any kind of human-disturbed environment. This review synthesizes 265 studies describing the distribution, morphology, biological and ecological traits of this morphospecies, as well as its impacts on soil conditions and communities. We then discuss the characteristics necessary for this specific morphospecies to become a successful colonizer throughout the world and the positive and negative effects it can have on the ecosystems that it has invaded. We emphasize the lack of knowledge of $P$. corethrurus reproductive mode and ploidy level, of its population genetics, and of the potential existence of cryptic species. To finish, we highlight the fact that data on $P$. corethrurus interactions with non-earthworm soil macrofauna are scarce.
\end{abstract}

\section{Introduction}

Earthworms are generally described as ecosystem engineers that greatly impact the physical, chemical and biological properties of soil (Blouin et al., 2013). Of the 3000-3500 earthworm species that have been described (Csuzdi, 2012), about 150 species are considered to be peregrine (i.e., widely ranging, often owing to human activity; Blakemore, 2012). Most of these peregrine earthworm species are well adapted to human transport and can colonize disturbed habitats (Hendrix et al., 2008). Climate may act as a barrier to their dispersal while their abundance may be limited by soil fertility and plant cover quality (Ortiz-gamino et al., 2016). It is also recognized that introduced species may cause changes to the ecosystem to which it has been introduced. For instance, European Lumbricidae such as Lumbricus rubellus or $L$. terrestris that have invaded previously glaciated regions in Canada and the USA have dramatically affected nutrient cycling and the functioning of the native ecosystems (Eisenhauer et al., 2011; Suárez et al., 2006).

Most of the species that are deliberately or inadvertently introduced into a new region fail to survive, and the majority of those that do survive, do not become invasive pests (Williamson and Fitter, 1996).
Introduced species pass through filters at four well-established spatiotemporal stages of invasion: introduction, establishment, landscape spread and integration (Vermeij, 1996). Species traits and environmental characteristics (Vermeij, 1996), as well as propagule pressure (propagule sizes, propagule numbers, and temporal and spatial patterns of propagule arrival) (Simberloff, 2009) may explain the success of these invasive species. Here, we discuss the case of Pontoscolex corethrurus, the quintessential peregrine earthworm in the tropics which has been successfully introduced worldwide. This endogeic earthworm tolerates a wide range of biotic and abiotic environmental conditions (Fragoso et al., 1999; Lavelle et al., 1987). It was first described in 1857 by Fritz Müller from Itajahy in the state of Santa Catarina in Brazil. Righi (1984) identified the Guyana shield as the original region of the Pontoscolex genus. Recently, Cunha et al. (2014), revealed the existence of two highly divergent genetic lineages within $P$. corethrurus in the island of Sao Miguel (Azores), suggesting the existence of cryptic species (i.e., different species which are not distinguishable morphologically). Thus, we choose to refer to the "morphospecies" P. corethrurus (i.e., a species distinguished from others only by its morphology) in this review. Cryptic species should be accounted for biological and ecological studies because different species may show differential

\footnotetext{
* Corresponding author.

** Corresponding author.

E-mail addresses: shabnam.taheri0@gmail.com (S. Taheri), lise.dupont@u-pec.fr (L. Dupont).
} 
adaptations to diverse environments and respond differently to perturbations.

$P$. corethrurus is one of the most studied tropical earthworm morphospecies in soil science (Fragoso et al., 1997; Plisko, 2001). It is used in ecotoxicological studies (Römbke and García, 2000), and it has been recommended as a bioindicator for the assessment of soil quality and ecosystem disturbances (Brown et al., 2006). Some restoration strategies of degraded soils have included the introduction of the morphospecies. For instance, it was used for the biofertilisation of tropical agricultural lands (Senapati et al., 1999; Topoliantz et al., 2002), the remediation of polluted sites (Duarte et al., 2012; Ganihar, 2003; García and Fragoso, 2002; Liang et al., 2011), and the improvement of phytoextraction treatments (Jusselme et al., 2012). Additionally, its use has been proposed in vermicomposting (Chaudhuri and Bhattacharjee, 2011; Molina-Murguia et al., 2009; Nath and Chaudhuri, 2012; Sabrina et al., 2013) and as a source of protein in animal feed for poultry and pork, and in fisheries (Brown et al., 2006). Although P. corethrurus may have a positive impact on soil ecosystems in certain circumstances, it may also negatively affect soil physical properties by increasing soil compaction. It may also modify biogeochemical processes as well as communities of plants, microbes and native earthworms (Marichal et al., 2010).

Four hypotheses have been put forward for explaining the success of invasive species: (i) they have traits that favour each stage of the invasion process, (ii) they exploit empty niches, (iii) they are favoured by anthropogenic pressure on natives and (iv) they are no longer under predatory, parasitic or competitive pressure (Sakai et al., 2001). Here, our objectives were (i) to address each of these hypotheses in order to describe the colonization success of the earthworm $P$. corethrurus in its pan-tropical region; due to the scarcity of data on the pathogens, parasites and predators of this species, the fourth hypothesis was not developed; (ii) to discuss the effects of the morphospecies in the introduced areas and (iii) to identify evidence in the literature suggesting the use of different cryptic species in experimental studies. We also identified knowledge gaps and provided promising perspectives for future research.

\section{Literature search}

The literature search was carried out using the keyword "Pontoscolex corethrurus" in Topics of the Web of Science databases using the 'All Databases' option. This option contained 'Web of Science TM Core Collection', 'Current Contents Connect', 'KCI-Korean Journal Database', 'MEDLINE', 'SciELO Citation Index' and 'CABI' research engines. We found 302 references published between 1900 and 2017. We also searched for synonymous species described by Blakemore (2006): Lumbricus corethrurus, Urochaeta corethrura, Pontoscolex arenicola, Urochaeta hystrix, Urochaeta dubia, Urochaeta, sp., Urochaeta australiensis, Pontoscolex hawaiensis, Pontoscolex guangdongensis and Pontoscolex corethrurus mexicana.

The articles written in English which were relevant for the review were sorted using the abstracts and the full texts. Moreover, the articles written in other languages and from which we could extract the information from the figures and tables, were also used. Finally, articles that did not focus specifically on P. corethrurus (e.g., when $P$. corethrurus was used for comparing results) were excluded. To complete the bibliographic corpus, some essential articles, which were not in the Web of Science, were collected from soil science specialists. The final corpus was composed of 265 references (Fig. 1). Most of the papers studied specimens collected outside the Guyana shield which is the putative native area of $P$. corethrurus. The greatest number of studies were conducted in India and Brazil, with 46 references each, followed by Mexico, with 39 references (Fig. 2).

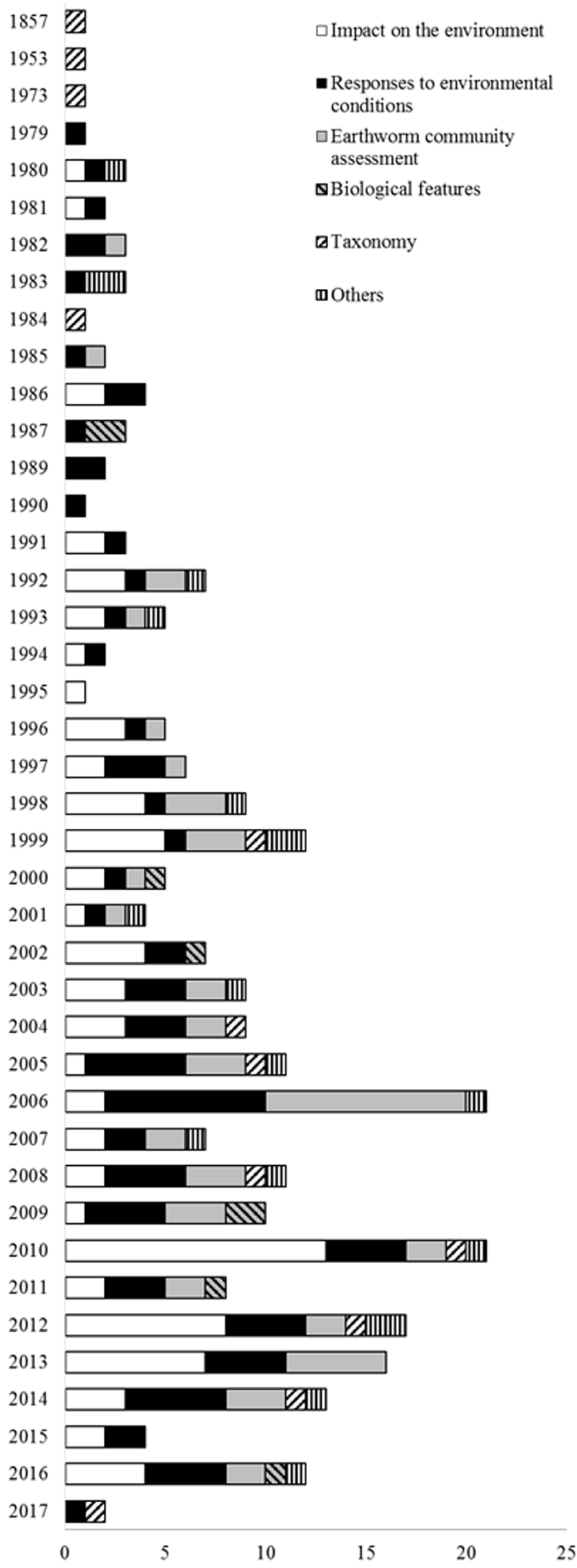

Fig. 1. Bibliographic corpus on P. corethrurus gathered in this review (source: ISI Web of Science). Papers were grouped into 6 different categories, corresponding to the most studied subjects on $P$. corethrurus: impact on the environment (33\% of the studies), responses to environmental conditions (32\%), earthworm community assessment (22\%), biological features (3\%), taxonomy (4\%) and other subjects (i.e., genetics, biochemistry, geographical distribution and digestion) (6\%). 


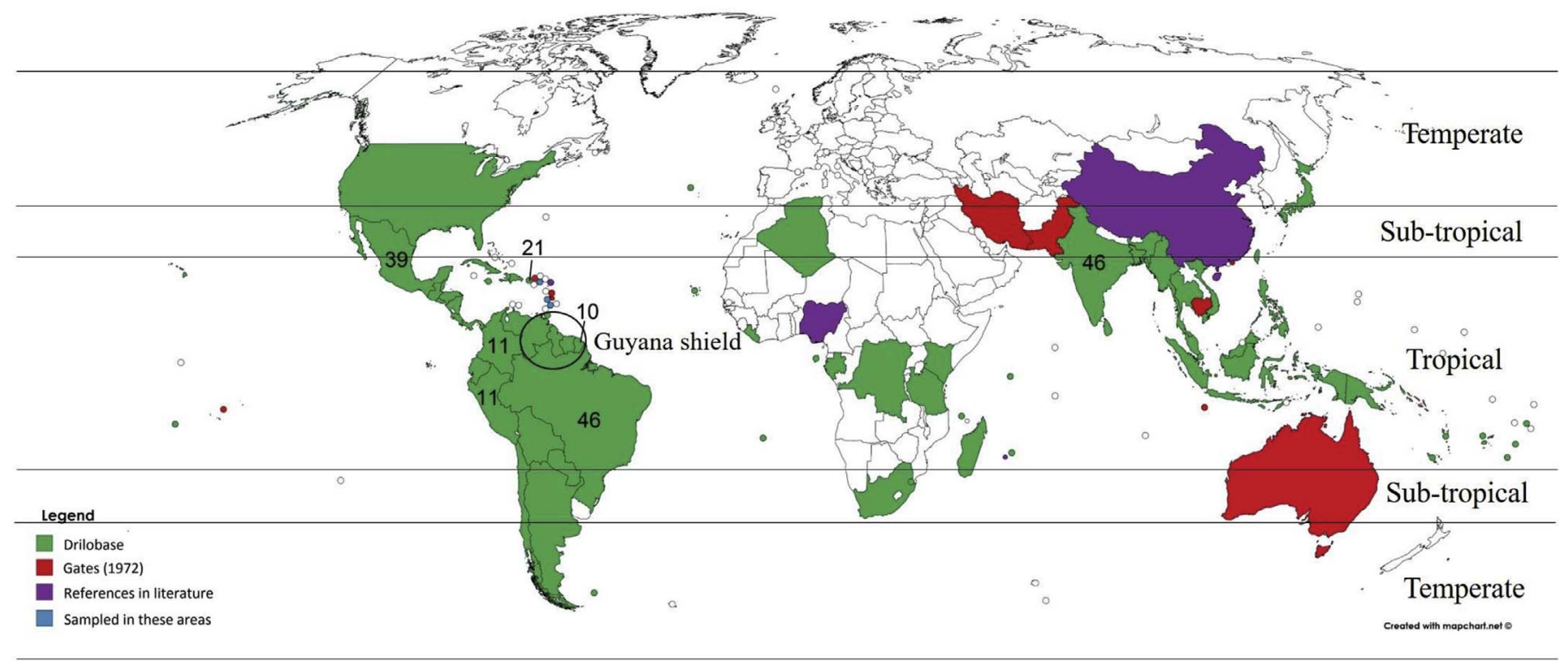

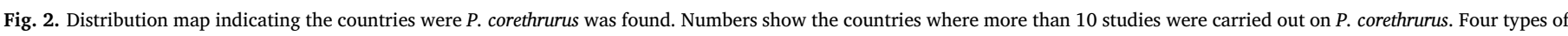

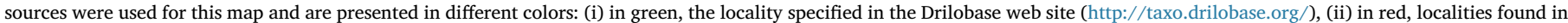

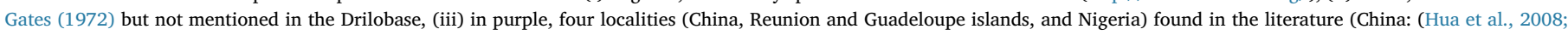

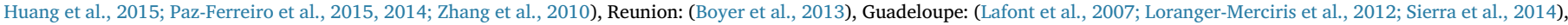

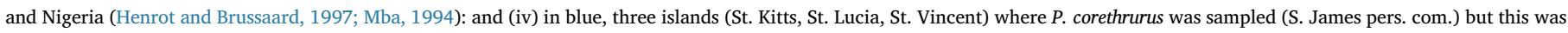

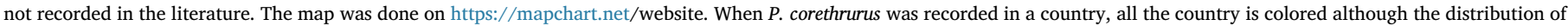

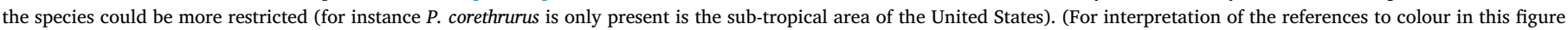
legend, the reader is referred to the web version of this article.)

\section{General results}

\subsection{Distribution and dispersal vectors}

Pontoscolex corethrurus has a widespread distribution, shown in Fig. 2. The map shows that it is present not only in tropical regions but also in sub-tropical zones. For instance, Ortiz-gamino et al. (2016) recorded its presence in sub-tropical regions of Mexico, at an elevation of 1550-1619 m above sea level (m.a.s.l.), and an average temperature of $17^{\circ} \pm 2$, where no other tropical species occur. This morphospecies was even recorded in the temperate zone, in the Azores archipelago (Cunha et al., 2014) and the Falkland islands (Reynolds and Jones, 2006). Gates (1972) mentioned that $P$. corethrurus was present in a greenhouse in the London suburb of Kew (United Kingdom), but there is no record of its expansion in this country.

Several vectors of passive dispersal may be involved in the spread of peregrine earthworms, e.g., transport of cocoons by streams and surface water, phoretic interactions with birds and mammals, transport by humans which can be accidental (with soil or potted plants) or commercial, for fishing bait and waste management industries ( $P$. corethrurus is most probably extensively transported by humans). Dupont et al. (2012) proposed that the accidental transfer of this morphospecies from Cayenne to the Nouragues reserve in French Guiana, which was revealed using the Amplified Fragment Length Polymorphism (AFLP) method, could be due to deliberate soil transfer for scientific experiments and accidental soil transfer on tools and shoes. Moreover, Brown et al. (2006) indicated that $P$. corethrurus is commonly used as fish-bait in Brazil. While González et al. (2006) highlighted the fact that its dispersal to the Caribbean Islands can be explained by human migration prior to European colonization, Blakemore (2006) suggested oceanic drafting as another vector of dispersal.

\subsection{Morphology}

Our purpose was not to describe in detail $P$. corethrurus morphological diagnosis but instead to highlight the main external and internal morphological traits mentioned in the literature. When reviewing 13 studies on $P$. corethrurus taxonomy (see Table 1 for references), we noticed some heterogeneity in the descriptions. For instance, some differences in the positions of the clitellum and tubercula pubertatis, which are key traits in earthworm taxonomy, were observed among papers. The beginning of the clitellum position has been identified in either XIV or XV segments while the end of it has been found in three different segments: XXI, XXII, and XXIII. The beginning of the tubercula pubertatis has been found in XV, XVIII and XIX segments and its ends in XXI, XXII and XXIII segments. Moreover, female, male and spermathecal pores have not always been observed (Table 1). Some traits were homogenous among references, such as the position of spermathecae and calciferous glands. The quincunx formation of setae on the last quarter of the body was mentioned in several studies. It is a character commonly used for the diagnosis of this species. However, Moreno (2004) highlighted the possibility of mistaking this species with others of the Pontoscolex genus by considering only this characteristic. Another diagnostic characteristic of the morphospecies is a special caudal zone described by Eisen (1896) and Gates (1973) of 4-7 segments (Table 1). The typhlosole which begins approximately at segment XXI ends with this caudal zone (Gates, 1973).

\subsection{Morphospecies traits and environmental characteristics}

\subsubsection{Reproductive strategy and fecundity}

Earthworms are usually hermaphrodites, meaning that both male and female organ systems, such as testes and ovaries, occur within a single individual. In $P$. corethrurus, male reproductive organs are often absent or atrophied (Gates, 1973; Tsai et al., 2000) and cocoons are viable without mating, thus suggesting a parthenogenetic reproduction (Chaudhuri and Bhattacharjee, 2011). In rare cases, Gates (1973) observed some iridescence in $P$. corethrurus spermathecae that raised the possibility of biparental reproduction. Sexual reproduction has also been suggested to occur by Dupont et al. (2012), based on a population genetics study.

This morphospecies is a continuous breeder with a high fecundity 
Table 1

Morphological characteristics of $P$. corethrurus described in 13 papers focusing on its taxonomy. External and internal morphological traits mentioned in more than 3 references were recorded. The positions are based on segments.

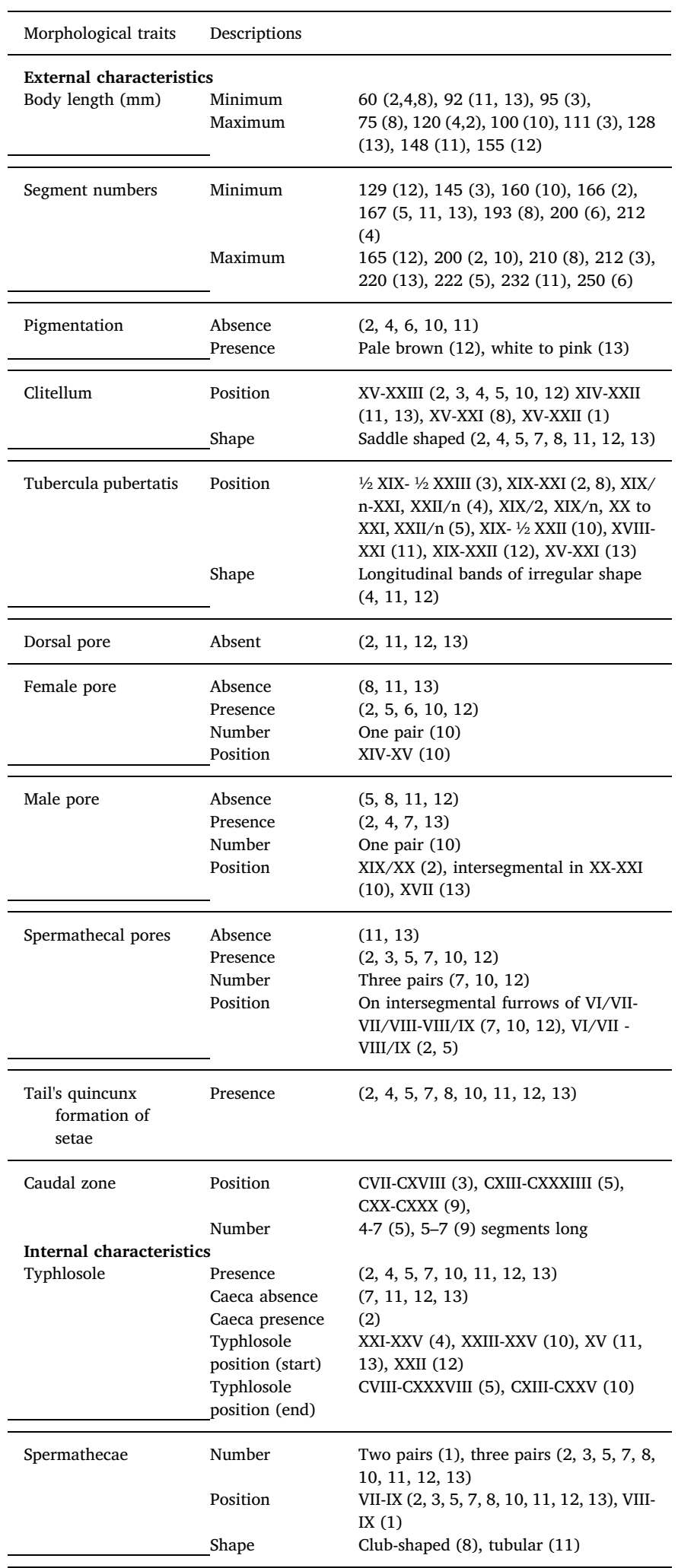

Table 1 (continued)

\begin{tabular}{lll}
\hline Morphological traits & Descriptions & \\
\hline Seminal vesicles & Absence & $(5)$ \\
& $\begin{array}{l}\text { Presence } \\
\text { Number }\end{array}$ & $\begin{array}{l}(2,4,5,7,10,11,12,13) \\
\text { One pair }(2,4,10,11,12,13), 8 \text { to } 10 \\
\text { segments long }(4,5)\end{array}$ \\
& Position & $\begin{array}{l}\text { XII }(2,12), \text { XV-XVII (11), XIII (13) } \\
\text { Saccular }(2,12), \text { follicular and flattened } \\
(11), \text { taped shape }(10)\end{array}$ \\
& Shape & Three pairs $(1,2,3,5,7,8,10,11,13)$ \\
\hline \multirow{2}{*}{ Calciferous glands } & Number & VII-IX $(1,2,3,5,7,8,10,11,12,13)$ \\
& Position & Lingular and flattened $(2)$, oval shaped \\
& Shape & $(11,13)$, tubular $(10,12)$, \\
& &
\end{tabular}

(1) (Beddard, 1893), (2) (Blakemore, 2006), (3) (Eisen, 1896), (4) (Gates, 1972), (5) (Gates, 1973), (6) (Müller, 1857), (7) (Narayanan et al., 2016), (8) (Nxele, 2012), (9) (Righi and Bittencourt, 1972), (10) (Righi, 1990) (11) (Shen and Yeo, 2005), (12) (Tripathi and Bhardwaj, 2005), (13) (Tsai et al., 2000).

rate (Gates, 1972; Vannucci, 1953). Under laboratory conditions, an adult of $P$. corethrurus can produce up to 145 cocoons per year (Arunachalam, 1987; Bhattacharjee and Chaudhuri, 2002; García and Fragoso, 2002). Cocoons have a short development time ranging from $21 \pm 1$ to $40 \pm 9$ days at $20-32{ }^{\circ} \mathrm{C}$ in laboratory (Arunachalam, 1987; Bhattacharjee and Chaudhuri, 2002; Chaudhuri and Bhattacharjee, 2011; Gates, 1972; Nair et al., 2009; Ortiz-ceballos et al., 2009). The hatching rate of cocoons is high, ranging from $78 \%$ to $97 \%$, depending on the temperature, in moist soil conditions (Lavelle et al., 1987). Generally, one hatchling is present per cocoon (Bhattacharjee and Chaudhuri, 2002; Vannucci, 1953; but see Nair et al., 2009). Before depositing their cocoons, $P$. corethrurus individuals build spherical nest chambers (mean diameter of $5.97 \pm 1.24 \mathrm{~mm}$ ) with their buccal appendix and coat the chambers with a fine layer of soil and mucus (Ortizceballos et al., 2009). Cocoons are then laid individually in these chambers (Hamoui, 1991; Vannucci, 1953). The nest chamber are surrounded by a 'feeding-chamber' where casts are deposited and where juvenile earthworms can come to feed once hatched (Ortiz-ceballos et al., 2009).

Research has revealed that $P$. corethrurus present a relative reproductive plasticity. For instance, this morphospecies has been shown to increase its rate of cocoon production and incubation period with increased temperature (Bhattacharjee and Chaudhuri, 2002). Moreover, García and Fragoso (2003) showed that individuals from the same population of $P$. corethrurus raised on different substrates displayed a possible physiological trade-off between cocoon number and cocoon weight, related to nitrogen $(\mathrm{N})$ limitations. In their experiment, $P$. corethrurus produced fewer but bigger cocoons $(>50 \mathrm{mg}$ ) in soils with high $\mathrm{N}$-availability and more but smaller cocoons $(<50 \mathrm{mg})$ when $\mathrm{N}$ was less available (García and Fragoso, 2003).

\subsubsection{Feeding habits, soil nutrient content and plant composition of the ecosystem}

The $P$. corethrurus diet is geophagous (i.e., feeding on soil) and can be classified between the polyhumic (i.e., ingesting soil with high organic matter content) and mesohumic (i.e., feeding indiscriminately on both mineral and organic particles) endogeic categories (Barois et al., 1999; Lavelle et al., 1987). Research has suggested that $P$. corethrurus may derive much of its tissue carbon (C) from rhizospheric sources (Spain et al., 1990) and fungal biomass may be its main source of $\mathrm{N}$ (Lachnicht et al., 2002).

Its abundance is positively affected by organic matter availability (García and Fragoso, 2002; Marichal et al., 2010; Ortiz-Gamino et al., 2016), N availability (Li et al., 2010; Marichal et al., 2010) and $P$ availability (Marichal et al., 2011) in the soil. Therefore, this morphospecies prefers rich soils in terms of organic matter and leaf litter (Liu and Zou, 2002; Ganihar, 2003; García and Fragoso, 2003). It is, 
however, worth noting that Ayala and Barois (2016) showed in a laboratory experiments that $P$. corethrurus was unable to grow in an extremely rich substrate of $75-100 \%$ organic matter, the mortality rate being between 56 and $100 \%$.

$P$. corethrurus is also able to feed in environments where litter resources are low (Lavelle et al., 1987; Marichal et al., 2010; Ponge et al., 2006; Shilenkova and Tiunov, 2015). For instance, $P$. corethrurus reached a remarkably high density $\left(200\right.$ ind. $\mathrm{m}^{-2}$ ) in a soil extremely poor in organic matter, the alluvial sandy soil of a gallery forest along the Dong Nai River in the Cat Tien National Park, southern Vietnam. The results of a microcosm experiment suggested that the high abundance of these earthworms in poor sandy soils might be due to assimilation of labile carbon released to the soil from plant roots (Shilenkova and Tiunov, 2015).

Plant species differ in the quantity and quality of litter produced, and these differences may significantly affect earthworm populations (Zou, 1993): the density of $P$. corethrurus was higher in Hawaiian plantations considered to have high litter quality (Albizia falcataria plantations) compared with plantations with lower litter quality ( $\mathrm{Eu}-$ calyptus saligna). Plants may affect earthworm populations in other ways; for instance León and Zou (2004) showed that the shift from grass vegetation (Axonopus compressus) to woody plants (Miconia prasina) in secondary forests of Puerto Rico decreased the abundance and biomass of $P$. corethrurus through reducing fine root biomass.

\subsubsection{Habitat}

3.3.3.1. Vegetative cover. P. corethrurus seems to proliferate in disturbed habitats (Marichal et al., 2010) and is often found to be dominant in croplands, pastures, urban areas and gardens (Table 2). However, $P$. corethrurus has also been found in forests (Table 2). In particular, it was found to be dominant in the primary forests of the Manzillo Wildlife Refuge and of the Tortuguero National Park in Costa-Rica (Lapied and Lavelle, 2003), in the tropical rainforests of Puerto-Rico (Zou and González, 1997) and in the cloud forest at the top of Luquillo Mountains (Liu and Zou, 2002), a result highlighting that this species also lives in undisturbed ecosystems.

3.3.3.2. Soil moisture and temperature. P. corethrurus populations are generally found in areas where the annual mean temperature is above $20{ }^{\circ} \mathrm{C}$. Reproduction being restricted to the $23-27{ }^{\circ} \mathrm{C}$ range, $P$. corethrurus growth to the adult stage is only possible between $20^{\circ}$ and $30{ }^{\circ} \mathrm{C}$ (Lavelle et al., 1987). Contrary to other tropical species (e.g., Meroscolex marcusi and Andiorrhinus caudatus), P. corethrurus is resistant to dehydration (Ayres and Guerra, 1981). However, if the soil moisture is too low (depending on the soil type), P. corethrurus may go into diapause (i.e., temporary suspension in development) (Chuang et al., 2004; Guerra, 1994). The use of soil moisture treatments as a gradient of "optimal-stress" environmental conditions by Fragoso and Lozano (1992), showed that juveniles and adults of $P$. corethrurus use different strategies for tissue regeneration. In juvenile worms, caudal amputation resulted in the initiation of diapause and, consequently, in the activation of the process of regeneration, independently of environmental conditions. Adults were only capable of regenerating tissue during diapause, which mainly occurred under conditions of environmental stress (soil dryness in the experiment). In a laboratory experiment, Zhang et al. (2008) showed that soil dryness was the primary factor limiting the reproduction of $P$. corethrurus.

3.3.3.3. Soil physico-chemical characteristics. Although P. corethrurus is found in a wide range of soil types (e.g., Entisol-Oxisol, Vertisol, Ferrasol, Ultisol, Fluvisol, and Andosol soils), Huerta et al. (2007) showed in Tabasco, Mexico that it prefers sites with high silt content (Fluvisol). It tolerates a wide range of soil pH (García and Fragoso, 2002; Lavelle et al., 1987) and, although it is often found in relatively acidic soil i.e., from 4.5 to 6.8 (Table 2, Teng et al., 2013), it favors soils with higher $\mathrm{pH}$. Studying a wide range of deforested soils of Eastern
Amazonia, Marichal et al. (2010) revealed that $P$. corethrurus densities covaried with $\mathrm{pH}$ and also with silt. Although it seems to favour soils with high pH, Marichal et al. (2012) found a positive relationship between mortality and $\mathrm{pH}$ in soil sampled in Eastern Brazilian Amazonian soils with high $\mathrm{pH}$ values (7.41 and 7.96). Juveniles seem more sensitive to $\mathrm{pH}$ than adults; Topoliantz et al. (2005) found that treatments increasing $\mathrm{pH}$, such as charcoal addition, promoted juvenile activity (i.e., casting).

3.3.3.4. Soil contaminants. Zavala-Cruz et al. (2012) proposed that the ability of $P$. corethrurus to colonize contaminated soils could be favoured by a genetic plasticity that confers a certain tolerance to pollutants or a specific genetic resistance to pollutants. P. corethrurus has indeed a broad tolerance towards soil contaminants and has been found in different polluted sites. For instance, $P$. corethrurus was the most abundant morphospecies $(75 \%$ of the total abundance of the community) in a site contaminated with hydrocarbons after an oil spill about 20 years previously in Tabasco, Mexico (Hernández-Castellanos et al., 2013), suggesting a high tolerance to benzo(a)pyrene (BaP).

A similar tolerance to trace elements has been reported by Duarte et al. (2014) in a lead (Pb) mining site in Southern Brazil. They showed that $P$. corethrurus biomass, cast production and survival rates were reduced only at high $\mathrm{Pb}$ soil concentrations $\left(9.716 \mu \mathrm{g} \mathrm{g}{ }^{-1}\right)$, compared to low and intermediate $\mathrm{Pb}$ concentrations (maximum $4.278 \mu \mathrm{g} \mathrm{g}^{-1}$ ). Similarly, $P$. corethrurus mortality, growth and cocoon production were affected only at high mercury $(\mathrm{Hg})$ concentrations (50 and $100 \mu \mathrm{g} \mathrm{g}^{-1}$ soil) after 56 days in a laboratory experiment with soils from forested sites in French Guiana (Da Silva et al., 2016). Buch et al. (2017) worked on soils of two Brazilian forest conservation units that had been polluted by $\mathrm{Hg}$ due to atmospheric deposition. They found cocoon production and earthworm growth to be affected at much lower concentrations of $\mathrm{Hg}$ i.e., $8 \mu \mathrm{g} \mathrm{g}^{-1}$ than that reported by Da Silva et al. (2016). At this concentration, $P$. corethrurus individuals were not found to avoid the contaminated soil. As with other contaminants and earthworm species (Pelosi et al., 2014), the bioavailability of chemicals in soils is highly dependent on soil properties (Van Gestel and Weeks, 2004). Therefore, the effects of trace elements on $P$. corethrurus are likely to depend on soil type, moisture, temperature and many other soil characteristics.

Only a few studies have investigated $P$. corethrurus sensitivity to pesticides. Kale and Krishnamoorthy (1979) assessed the effects of the insecticide Sevin (i.e., 1-naphthyl-n-methylcarbamate) which was mixed with a clay loam in the laboratory. They found the lower concentrations (i.e., 37.5-75 ppm) to have a stimulatory effect on earthworm growth and survival rather than an inhibitory effect. However, the highest concentrations (i.e., > $150 \mathrm{ppm}$ ) resulted in growth delays and reduced rates of survival. Forster et al. (2006) showed that $P$. corethrurus was very sensitive to the fungicide carbendazim. This fungicide, forbidden in Europe since 2009, caused a decrease in $P$. corethrurus abundance during a three-month experiment under laboratory conditions using intact soil-core terrestrial model ecosystems (TMEs). This result was confirmed by Buch et al. (2013) who revealed that carbendazim at $3.16 \mathrm{mg}$ a.i. $\mathrm{kg}^{-1}$ and the insecticide carbofuran at $5 \mathrm{mg}$ a.i.kg ${ }^{-1}$ applied in boxes filled with artificial tropical soil (TAS, a substrate used in ecotoxicological tests (OECD, 1984)) had lethal effects on this morphospecies.

Finally, the response of $P$. corethrurus to herbicides is variable, as it is for the other contaminants mentioned above. Even at the highest concentrations of a glyphosate-based herbicide (GBH) $\left(47 \mathrm{mg}\right.$ a.i. $\left.\mathrm{kg}^{-1}\right)$, Buch et al. (2013) did not find any significant effect on mortality. Conversely, García-Pérez et al. (2014) showed that GBH could have lethal impacts on $P$. corethrurus, as the application of GBH to coffee plantations thrice a year caused significant reduction in $P$. corethrurus density (167 and 353 ind. $\mathrm{m}^{-2}$ with and without herbicide, respectively) and biomass (23 and $45 \mathrm{~g} \mathrm{~m}^{-2}$ with and without herbicide, respectively). However, in another study under laboratory conditions 
Table 2

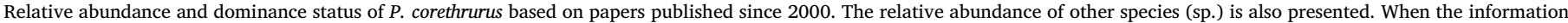
was available, it is indicated when the species was considered dominant (D).

\begin{tabular}{|c|c|c|c|c|c|c|c|c|}
\hline \multirow[t]{2}{*}{ Habitat } & & \multirow[t]{2}{*}{ Country } & \multirow[t]{2}{*}{ Soil pH } & \multicolumn{4}{|c|}{ Relative abundance (\%) } & \multirow[t]{2}{*}{$\operatorname{Ref}^{a}$} \\
\hline & & & & P. corethrurus & other exotic sp & native sp & undefined origin sp & \\
\hline \multirow[t]{27}{*}{ Forest } & Secondary forest & Brazil & - & 25.0 & 75.0 & - & - & 1 \\
\hline & Disturbed native forest & Brazil & 5 & - & 100 & - & - & 2 \\
\hline & Forest of the Cahuita National Park & Costa Rica & _- & $68.2(\mathrm{D})$ & 31.8 & - & - & 3 \\
\hline & Peripheric primary forest of Tortuguero National Park & Costa Rica & 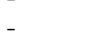 & 100 (D) & - & - & - & 3 \\
\hline & Primary forest of the Manzanillo Wildlife Refuge & Costa Rica & - & 91.4 (D) & 8.6 & - & - & 3 \\
\hline & Remote primary forest of Tortuguero National Park & Costa Rica & 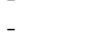 & - & - & 100 & - & 3 \\
\hline & Forest & Cuba & 5.62 & $65.8(\mathrm{D})$ & 21.4 & 12.8 & - & 4 \\
\hline & Mixed forest & India & 4.62 & $28(\mathrm{D})$ & 22.3 & 49.7 & - & 5 \\
\hline & Elfin woodland & Puerto Rico & _- & 14.7 & 16.5 & 68.8 & - & 6 \\
\hline & Flooded Pterocarpus & Puerto Rico & - & - & - & 100 & - & 6 \\
\hline & Lowland moist forest & Puerto Rico & - & 51.5 & 34 & 14.5 & - & 6 \\
\hline & Lowland dry forest & Puerto Rico & - & - & 100 & - & 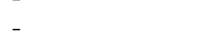 & 6 \\
\hline & Palo colorado forest & Puerto Rico & - & 51.7 & - & 48.3 & - & 6 \\
\hline & Sierra palm forest & Puerto Rico & - & 85.7 & 2.4 & 11.9 & - & 6 \\
\hline & Tabonuco forest & Puerto Rico & - & 80.2 & 2.4 & 17.4 & - & 6 \\
\hline & Forest with coffee (Coffea arabica) & Puerto Rico & $6.7-6.8$ & 100 (D) & - & - & - & 7 \\
\hline & Forest with fern (Dicranoteris flexusosa) & Puerto Rico & $5.8-6.8$ & 100 (D) & - & - & - & 7 \\
\hline & Forest with Selaginella spp. & Puerto Rico & $5.3-5.9$ & 79.0 (D) & - & 21.0 & - & 7 \\
\hline & Maricao State Forest & Puerto Rico & $4.5-5.0$ & 98.0 (D) & - & 2.0 & - & 8 \\
\hline & Wet forest (well-drained areas) & Puerto Rico & 4.7 & 97.0 (D) & & 1.0 & 2.0 & 9 \\
\hline & Wet forest (Tabonuco forest) & Puerto Rico & 5.9 & $95.0(\mathrm{D})$ & & & 5.0 & 9 \\
\hline & Fresh water swamp forest & Singapore & - & 86.0 & - & - & 14.0 & 10 \\
\hline & Bukit Timah nature reserve (foret) & Singapore & - & 12.5 & 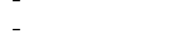 & - & 87.5 & 10 \\
\hline & Upper seletar resevoir park (foret) & Singapore & - & 91.6 & 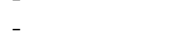 & - & 8.4 & 10 \\
\hline & Dry evergreen forest & Thailand & - & 58.8 & - & - & 41.2 & 11 \\
\hline & Dry dipterocarp forest fired & Thailand & - & - & - & - & 100 & 11 \\
\hline & Dry dipterocarp forest-non fired & Thailand & - & - & - & - & 100 & 11 \\
\hline Wetland & $\begin{array}{l}\text { Sungei buloh wetland reserve (covered with } \\
\text { mangroves) }\end{array}$ & Singapore & - & 87.2 & - & - & 12.8 & 10 \\
\hline \multirow[t]{11}{*}{ Pasture and grassland } & Cultivated pasture & Brazil & 5.3 & 50.0 & 50.0 & - & - & 2 \\
\hline & Perennial pasture & Brazil & 4.6 & - & 100 & - & - & 2 \\
\hline & Old pastures 1 & Brazil & - & 43.0 & 39.0 & 18.0 & - & 1 \\
\hline & Old pastures 2 & Brazil & - & 96.0 (D) & 2.1 & 1.9 & - & 1 \\
\hline & Pasture & Cuba & 5.6 & 11.3 & 74.8 (D) & 13.9 & - & 4 \\
\hline & Pasture (extensive cattle farming) 1 & Mexico & 6.6 & 19.6 & - & 80.4 & - & 12 \\
\hline & Pasture (extensive cattle farming) 2 & Mexico & 6.6 & 37.0 & 63.0 & - & - & 12 \\
\hline & Pasture (semi-intensive cattle farming) 1 & Mexico & 5.5 & 46.0 & 54.0 & - & - & 12 \\
\hline & Pasture (semi-intensive cattle farming) 2 & Mexico & 5.6 & - & 100 & - & - & 12 \\
\hline & Rifle range (grass field) & Singapore & - & 54.1 & - & - & 45.9 & 10 \\
\hline & Grassland & Thailand & - & 55.6 & - & - & 44.4 & 11 \\
\hline \multirow[t]{17}{*}{ Culture and plantation } & Grain crop (converted from an old pasture) & Brazil & - & $87.0(\mathrm{D})$ & 8.3 & 4.7 & - & 1 \\
\hline & Grain crop field 1 & Brazil & - & 0 & 66.5 & 33.5 & - & 1 \\
\hline & Grain crop field 2 & Brazil & - & 0 & 30.0 & $70.0(\mathrm{D})$ & - & 1 \\
\hline & Sugarcane (Saccharum sp.) 2 & Brazil & 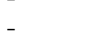 & 10.0 & 60.0 & 30.0 & - & 1 \\
\hline & Sugarcane (Saccharum sp.) 1 & Brazil & - & 41.0 & 50.0 & 9.0 & - & 1 \\
\hline & Manduirana plantation & Brazil & 5.6 & - & 100 & - & 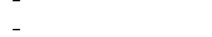 & 2 \\
\hline & Banana plantation & Costa Rica & - & 100 (D) & - & - & - & 3 \\
\hline & Mixed fruit plantation & India & - & 20.0 & 8.3 & 71.7 (D) & - & 13 \\
\hline & Pineapple plantation & India & - & 10.4 & 1.9 & 87.7 (D) & - & 13 \\
\hline & Rubber plantation & India & 4.7 & 71.8 (D) & 5.4 & 22.8 & 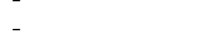 & 14 \\
\hline & Rubber plantation & India & 4.5 & 76.5(D) & 3.3 & 20.2 & - & 5 \\
\hline & Agricultural ecosystem & Malaysia & 6.1 & 7.8 & - & - & $92.2(\mathrm{D})$ & 15 \\
\hline & Rice paddy & Thailand & - & 27.3 & - & - & 72.7 & 11 \\
\hline & Cassava plantation & Thailand & - & 55.8 & - & - & 44.2 & 11 \\
\hline & Forest plantation & Thailand & - & 93.3 & - & - & 6.7 & 11 \\
\hline & Mango plantation & Thailand & - & 71.4 & - & - & 28.6 & 11 \\
\hline & Sugarcane plantation & Thailand & - & - & - & - & 100 & 11 \\
\hline \multirow[t]{10}{*}{ Urban area and gardens } & Lawn & Brazil & 4.6 & 25.0 & 75.0 & - & - & 2 \\
\hline & Bribri village & Costa Rica & - & $100(\mathrm{D})$ & - & - & - & 3 \\
\hline & Cahuita village & Costa Rica & - & 91.8 (D) & 8.2 & - & 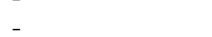 & 3 \\
\hline & Puerto Viejo village & Costa Rica & - & 89.7 (D) & 10.3 & - & - & 3 \\
\hline & Campus of National University of Singapore & Singapore & - & 16.7 & - & - & 83.3 & 10 \\
\hline & Kranji wireless station & Singapore & - & 80.8 & - & - & 19.2 & 10 \\
\hline & Singapore botanic gardens & Singapore & 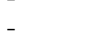 & 91.7 & - & - & 8.3 & 10 \\
\hline & Household area & Thailand & - & 27.2 & - & - & 72.8 & 11 \\
\hline & Office building area 1 & Thailand & 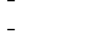 & 52.0 & - & - & 48.0 & 11 \\
\hline & Office building area 2 & Thailand & - & 51.0 & 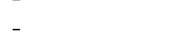 & - & 49.0 & 11 \\
\hline
\end{tabular}

a References: (1) (Nunes et al., 2006), (2) (Ressetti, 2006), (3) (Lapied and Lavelle, 2003), (4) (Martinez and Sanchez, 2000), (5) (Chaudhuri and Nath, 2011), (6) (González et al.,

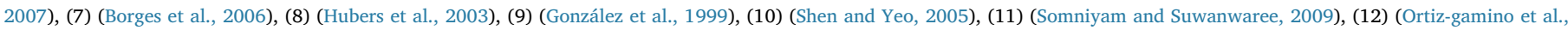


by the same authors, earthworms exposed to a Coffea litter polluted by GBH produced the same number of cocoons as $P$. corethrurus fed with the unpolluted litter (García-pérez et al., 2016).

\subsection{Impact of $P$. corethrurus on its environment}

\subsubsection{Physical impacts on soil structure}

$P$. corethrurus is known to compact soil. As a consequence of its feeding activity, small aggregates are progressively transformed into larger aggregates which tend to accumulate in the absence of other agents that break down these larger aggregates; the soil is thus progressively compacted (Alegre et al., 1996; Blanchart et al., 1997). The accumulation of casts by $P$. corethrurus at the soil surface under moist soil conditions may result in the formation of a continuous muddy layer of earthworm casts if "decompacting" activities by other invertebrate populations are too weak. The growth of plants is then prevented and when droughts occur, this layer turns into a compact thick crust. As a consequence, large patches of bare soil impermeable to water and air are generated (Chauvel et al., 1999). Alegre et al. (1996) observed a significant increase in bulk density from 1.12 to $1.23 \mathrm{~g} \mathrm{~cm}^{-3}$ and a decrease in porosity from $58 \%$ to $53 \%$ in the presence of $P$. corethrurus in a loamy soil in Peru. Similar changes were found in a reciprocal transplant study by Barros et al. (2001) where blocks of forest soil with $48 \%$ porosity (in an experimental station in Central Amazonia in Brazil) were transferred to a pasture with $16 \%$ porosity where $P$. corethrurus was very abundant ( 400 ind. $\mathrm{m}^{-2}$ ) and vice versa. After 1 year, the transplanted blocks of forest soil presented a porosity of $26 \%$, whilst the transplanted blocks of pasture soil presented a porosity of $34 \%$.

By contrast, in certain circumstances, $P$. corethrurus contributed to soil bioturbation processes and decreased soil compaction. Zund et al. (1997) demonstrated that the presence of $P$. corethrurus decreased bulk density and increased aeration of a compacted Oxisol from Australia. Moreover, Hallaire et al. (2000) showed, in a sandy loam soil in Yurimaguas, Peru, that $P$. corethrurus activity induced a compaction of the surface soil, through a coalescence of casts, in plots without organic inputs whereas they created a crumb structure in plots with high soil organic matter contents. Although it is generally accepted that soil compaction by macroaggregation occurs when soil organic matter (SOM) is missing, Sparovek et al. (1999) showed that $P$. corethrurus inoculation, with or without organic matter amendment, resulted in soil compaction in an acidic Oxisol of Brazil.

\subsubsection{Chemical impacts}

3.4.2.1. Organic matter mineralization and nutrient cycling. Earthworm activity via the production of casts is recognized as an important factor affecting $\mathrm{C}, \mathrm{N}$ and phosphorus (P) cycles in the soil and $\mathrm{CO}_{2}$ and $\mathrm{N}_{2} \mathrm{O}$ fluxes from the soil to the atmosphere (Chapuis-Lardy et al., 2010; Jiménez et al., 2003; Lavelle et al., 1998). The activity of such endogeic geophagous earthworms is often considered to increase C mineralization in the short term and favour $\mathrm{C}$ storage through the stabilization of SOM in stable micro-aggregates in the long term (Lavelle et al., 1997; Lavelle and Martin, 1992; Lavelle and Spain, 2001). The influence of earthworms on SOM and nutrient dynamics may depend on a number of factors including the time frame in question but also inherent soil properties, the form of management in place (Fonte et al., 2010) and the interaction with plants (Fonte et al., 2012). Using microcosm experiments, Fonte et al. (2010) showed that, in the first $15 \mathrm{~cm}$ layer of the soil, $P$. corethrurus decreased the total soil C by 3\% under the Quesungual slash-and-mulch agroforestry system of western Honduras (QSMAS). The QSMAS is an agricultural system with short fallow periods and promoted by extension agents with the intention of reducing the slash-and-burn agricultural strategy (Pauli et al., 2005). By comparing treatments with and without earthworms in maize crops under no tillage in the Peruvian Amazonia, Desjardins et al.
(2003) showed that the total carbon content of the $0-10 \mathrm{~cm}$ depth was dramatically reduced by $28 \%$ in the earthworm - inoculated plots. The results of a 5 months incubation of $P$. corethrurus with added rice and soybean residues suggested that incorporation of organic $C$ by earthworm was higher with smaller rice residues than with larger and woodier soybean residues (Coq et al., 2007).

Earthworm activity is recognized to be an important factor in regulating $\mathrm{CO}_{2}$ fluxes from the soil to the atmosphere (Speratti and Whalen, 2008). We found only one laboratory study investigating this issue with $P$. corethrurus. The study showed that its presence in Ferralsol of Madagascar induced a significant increase in $\mathrm{CO}_{2}$ emissions (Chapuis-Lardy et al., 2010).

In addition to its effects on C dynamics, $P$. corethrurus is known to enhance N mineralization and availability (Araujo et al., 2004; González and Zou, 1999; Lafont et al., 2007; Lavelle et al., 1992; TapiaCoral et al., 2006). For instance, Lavelle et al. (1992) showed that mineral $\mathrm{N}$ concentrations ranged from 133.1 to $167.8 \mu \mathrm{g} N$ per gram dry soil in fresh casts of this morphospecies fed on an Amazonian Ultisol. This was approximately five times higher than the concentration in the non-ingested soil. Similarly, Pashanasi et al. (1992) and Araujo et al. (2004) found that the introduction of $P$. corethrurus significantly increased the soil microbial biomass- $\mathrm{N}$ (bio-N) and mineral- $\mathrm{N}$ availability in various experiments. However, in a mesocosm experiment, Fonte and Six (2010) found no significant effect of P. corethrurus on potentially mineralizable $\mathrm{N}$ using a method that measured relatively labile sources of organic $\mathrm{N}$.

Finally, it is generally accepted that earthworms increase P availability across a wide range of agroecosystems (Jiménez et al., 2003; Lopez-Hernandez et al., 1993). A significant increase of exchangeable phosphate was observed in the casts of $P$. corethrurus in several experiments carried out in mesocosms using topsoil dug to a maximum of $25 \mathrm{~cm}$ depth (Chapuis-Lardy and Brossard, 1995; Chapuis-Lardy et al., 1998, 2009; Lopez-Hernandez et al., 1993; Sabrina et al., 2013), thus confirming its important contribution to phosphate cycling in tropical soil surface layer. Surprisingly, Fonte and Six (2010) observed a decrease in $P$ availability in presence of $P$. corethrurus in the surface $15 \mathrm{~cm}$ of mesocosms that were incubated under field conditions within the QSMAS in western Honduras. They proposed that increased P enrichment and availability in casts comes at the expense of lower P content and availability in non-ingested soil.

3.4.2.2. Metal mobility and availability in soils. In general, earthworms increase the availability and mobility of essential (e.g., $\mathrm{Zn}, \mathrm{Cu}, \mathrm{Mn}, \mathrm{Fe}$ ) and non-essential (e.g., $\mathrm{Cd}, \mathrm{Pb}, \mathrm{Hg}$ ) metals in both contaminated and uncontaminated soils (Sizmur and Hodson, 2009). Using a sequential extraction procedure, Duarte et al. (2012) revealed that $P$. corethrurus significantly reduced the amount of $\mathrm{Pb}$ in the soluble and exchangeable forms in the soil, and increased the $\mathrm{Pb}$ bound in $\mathrm{Fe}$ and $\mathrm{Mn}$ oxides in the casts. This can be beneficial for soil bioremediation. In addition, Jusselme et al. (2015) found that $P$. corethrurus has an indirect impact on the $\mathrm{Pb}$ phytoextraction ability of Lantana camara. The presence of earthworms enhanced L. camara biomass by about 1.5-2 times, thereby increasing the uptake of $\mathrm{Pb}$ two to threefold (Jusselme et al., 2015).

\subsubsection{Impact on biotic factors}

3.4.3.1. Effect on other earthworm species. Pontoscolex corethrurus may reach high densities in some areas. Marichal et al. (2010) surveyed 270 sites in Brazil and Colombia and showed that where P. corethrurus occurred, its average density was 90.2 ind. $\mathrm{m}^{-2}$, ranging from 5.3 to 567 ind. $\mathrm{m}^{-2}$. The density of $P$. corethrurus populations is often inversely correlated with the density of other earthworm species (Chaudhuri and Nath, 2011; González et al., 1996; Lapied and Lavelle, 2003; Römbke et al., 2009).

Some studies have suggested that an increase in density of $P$. 
corethrurus could cause the loss of native species populations (Fragoso et al., 1995; Lapied and Lavelle, 2003). However, the coexistence of this morphospecies with native species has been observed in several sites of different forests in Cuba, India, Puerto Rico, in pastures in Brazil, Cuba and Mexico and in cultures and plantations in Brazil and India (Table 2). The coexistence or replacement of native earthworms by exotic ones may depend on the disturbance history and the state of naturalness of the landscape (González et al., 2006). Different relationships among $P$. corethrurus and native earthworms may depend on the specific context of the study area. For instance, in a mid-altitude Tabonuco forest (400 m above sea level) in Puerto Rico, Hendrix et al. (1999) showed that the niches of $P$. corethrurus and the native earthworm Estherella sp. Overlapped completely in sites rich in $\mathrm{N}$ resources. On the other hand, in a tropical forest in Puerto Rico, Lachnicht et al. (2002) found the activity of Estherella sp. and P. corethrurus to be spatially separated, and it appeared that they excluded each other from bottom and surface layers. Marichal et al. (2010) suggested that the replacement of native species by $P$. corethrurus is a result of changes in the environment, such as deforestation in tropical rainforest areas, that affect both groups of species differently, rather than the result of competition between invasive and native species. They proposed that while native species tend to disappear because of the destruction of their habitats and reduction of their food sources, $P$. corethrurus can occupy the soil with increased $\mathrm{pH}, \mathrm{C}$ and nutrient contents created by the deforestation and burning.

In some cases, the dominance of native species over $P$. corethrurus was found, such as in pineapple plantations of West Tripura in India where the endogeic native species Drawida assamensis was dominant although P. corethrurus was present (Table 2, Dey and Chaudhuri, 2014).

Lastly, $P$. corethrurus may coexist with other exotic earthworm species (Table 2) such as Dichogaster spp in Brazil and Costa Rica(Lapied and Lavelle, 2003; Nunes et al., 2006), Ocnerodrilus occidentalis and Drawida barwelli in Puerto Rico and Cuba (González et al., 2007; Martinez and Sanchez, 2000) Amynthas gracilis and Octolasion tyrtaeum in Mexico (Ortiz-gamino et al., 2016) and Metaphire houlleti, M. posthuma, Perionyx excavatus and Amynthus alexandri in India (Dey and Chaudhuri, 2014).

3.4.3.2. Effect on nematodes. Earthworms can have either a direct (e.g., by ingestion) or an indirect (i.e., by physical and chemical changes of soil properties) impact on plant-feeding nematodes (Blouin et al., 2005; Lafont et al., 2007; Senapati, 1992; Wurst, 2010). Under laboratory conditions, Boyer et al. (2013) revealed a decrease in Heterodera sacchari and Pratylenchus zeae populations, two plant parasitic nematodes, in the presence of $P$. corethrurus. They highlighted a transit effect on nematode populations during the passage through the earthworm gut. However, Lafont et al. (2007) and LorangerMerciris et al. (2012) found that the density of the banana feeding nematodes Radopholus similis, Pratylenchus coffeae and Helicotylenchus multicinctus did not significantly decrease in presence of $P$. corethrurus in microcosm experiments, although they observed significantly less root damage induced by nematodes. Finally, $P$. corethrurus may have a positive effect on total nematode densities, as shown by Villenave et al. (2010) in a 5-month field mesocosm experiment conducted in Madagascar. The authors revealed that $P$. corethrurus stimulated the microbial community, which increased the density of the dominant microbiovorous bacterial-feeding and fungal-feeding nematodes.

3.4.3.3. Effect on soil microorganisms. Endogeic earthworms have developed complex interactions with soil microorganisms. In particular, the digestion process in the earthworm gut is known to enhance microbial activity (Barois and Lavelle, 1986; Drake and Horn, 2007). The feeding activity of $P$. corethrurus has been shown to result in increased microbial biomass and activity in casts after soil was passed through the gut and excreted (Barois, 1992; Barois and Lavelle, 1986;
Bernard et al., 2012). Thus, $P$. corethrurus has provided a basis for the 'sleeping beauty' hypothesis where water and soluble-C in the form of intestinal mucus produced by the earthworm awakens dormant microbial communities in the gut, thereby increasing mineralization of the stable forms of SOM ingested (Lavelle et al., 1983). While dormant microorganisms may be activated during their transit through the gut, others remain unaffected, and yet others digested in the intestinal tract (Drake and Horn, 2007). Barois (1992) pointed out dissimilarities of gut microbial activity among $P$. corethrurus populations suggesting that different populations might show differences in physiological genetics and/or in the intensity of the mutualism with the soil microbial communities. This latter study also demonstrated that temperature has a direct effect in triggering microbial activity within the gut of $P$. corethrurus.

3.4.3.4. Effect on plants. Earthworms generally have positive effects on plant growth in the tropics (Brown et al., 1999) by affecting soil maccroaggregation and availability of nutrients. We previously highlighted (section 3.4.1) that soil macroaggregation by $P$. corethrurus often resulted in increased soil bulk density, and decreased total soil porosity and water infiltration, along with some changes in the soil moisture patterns. Such changes in a sandy loamy soil might be beneficial to some crops such as shown by Alegre et al. (1996) for rice cowpea and maize. Pashanasi et al. (1996) showed that the inoculation of $P$. corethrurus at a density of 90 ind. $\mathrm{m}^{-2}$ had a positive effect on soil properties and plant production in low-input cropping systems at Yurimaguas (Peru), although this positive effect varied depending on rainfall, plants and organic inputs. In particular, maize seemed to respond better than rice to earthworm effects, while cowpea did not respond at all.

A major factor affecting plant growth, in relation to the presence of earthworms, is the availability of resources. If the casts, which are enriched in nutrients necessary for plant growth such as N, P, and potassium (K) (Chaudhuri et al., 2012; Lopez-Hernandez et al., 1993) are deposited close to plant roots, they can have significant positive impacts on plant growth (Lavelle et al., 1992). For instance, LorangerMerciris et al. (2012) showed that $P$. corethrurus enhanced dessert banana growth through increased $P$ availability in its casts. In another study, the presence of $P$. corethrurus increased aboveground biomass of Brachiaria decumbens by $30 \%$, via increased availability of soil nutrients (Fonte et al., 2012).

The activity of $P$. corethrurus may also promote plant health. Teng et al. (2016) demonstrated that the severity of banana blood disease (i.e., a destructive bacterial infection caused by Ralstonia solanacearum) decreased after the inoculation of $P$. corethrurus. This process was explained by a higher plant biomass in comparison to controls, as roots were exposed to high densities of beneficial microorganisms through burrowing and casting activities of the earthworms (Teng et al., 2016).

\section{Discussion}

\subsection{Components of P. corethrurus invasion success}

Identifying traits correlated with invasiveness is a central goal in invasion ecology. It is generally agreed that distinct characteristics are important during different stages of the invasion process (e.g., Ribeiro et al., 2008). In particular life history traits (i.e., traits involved in reproduction, growth and survival) may help to differentiate potentially successful and unsuccessful invaders (Sol et al., 2012). During the first stage of the invasion, which is the arrival of a species in a new habitat, one or more propagules of a species must first be carried and survive the dispersal. Most long-distance introductions of $P$. corethrurus to new areas are the direct or indirect result of human activities. This earthworm was thus transported throughout the world (Fig. 2) and these events that were probably recurrent are extremely difficult to date.

Once propagules are introduced, a successful invader must establish 
a reproducing population. $P$. corethrurus is a continuous breeder with a high fecundity rate, a high hatching success and a short development time (Lavelle, 1981). Organisms with such characteristics are often classified as r-selected and recognized to be frequently colonizing species (Bufford and Daehler, 2011). The fact that $P$. corethrurus can reproduce by parthenogenesis predisposes this species to invasiveness. Indeed, the ability of a single individual to establish a population is an important characteristic of many invasive species (e.g. Dybdahl and Drown, 2011). Yet, parthenogenetic species lack the capacity to generate novel genetic variation necessary for evolvability (i.e., the ability of a population to adapt in response to environmentally induced stress, Waddington, 1965) due to the absence of bi-parental reproduction and genetic recombination. It has been suggested however, that $P$. corethrurus is capable of bi-parental reproduction (Dupont et al., 2012; Gates, 1973). Such a mixed-mating system, allowing reproduction through inbreeding and outbreeding according to mating possibilities, is a trait that may favour the rapid establishment of an exotic species in new areas (Dupont et al., 2007). The possibility of sexual reproduction should be investigated by genotyping parents and offspring from cross experiments. Moreover, knowledge of the ploidy level of $P$. corethrurus could help to better understand its reproductive mode. Indeed, parthenogenesis is closely linked to polyploidy in earthworms and odd number of chromosomes are often incompatible with sexual reproduction (Shen et al., 2011).

Competitive ability is another trait that may confer an advantage for invasive species during establishment. Many studies have documented invaders that show a superior ability to exploit local resources when compared with native residents (Sakai et al., 2001). Plasticity, i.e., the ability of an organism to cope with a wide variety of habitats and conditions, is thus an important factor in the success of the establishment step (Bufford and Daehler, 2011). P. corethrurus is described as euryecic (i.e., of wide ecological plasticity). For instance, $P$. corethrurus has a broad tolerance towards soil contaminants. Its fitness (i.e., individual reproductive success to participate in next generation pool gene) in different polluted sites is affected only at high pollutant concentrations. $P$. corethrurus also presents a reproductive plasticity; an adjustment of cocoon production (number and weight) and incubation period have been observed in different situations (Bhattacharjee and Chaudhuri, 2002; García and Fragoso, 2003).

Another important sign of plasticity of this species is its flexible diet. Although $P$. corethrurus prefers rich soils in terms of organic matter and leaf litters, it is able to proliferate in extremely poor soils (Shilenkova and Tiunov, 2015). Marichal et al. (2010) proposed that $P$. corethrurus can occupy soils where other earthworm species are not present or have disappeared due to soil use and management.

In addition to the invasiveness of the species, another component of the invasion success is the invasibility of the recipient ecosystem (Mitchell et al., 2006). The hypothesis of ecological opportunity proposes that extinction of native species, and in consequence the creation of 'empty' niches, promote the establishment of exotic species (Elton, 1958). Since human-caused environmental changes may alter native species survival, they may favour a few introduced species that would competitively displace many other species from a region (Tilman and Lehman, 2001). Land use history plays thus a major role in determining the abundance and community structure of earthworms and the establishment of exotic earthworms in areas previously inhabited by native worms. For example, in the tropics, the conversion of forest to pastures has been associated with significant decreases in soil macroinvertebrate diversity (Lavelle and Pashanasi, 1989) and an increased dominance of a few exotic earthworm species that can persist along gradients of plant succession after disturbance (León et al., 2003; Zou and González, 1997). Although invasion by P. corethrurus has been also observed in undisturbed habitats (González et al., 2006; Hendrix et al., 1999), it seems that land use conversion is a main reason for $P$. corethrurus dominance in different parts of the world (Marichal et al., 2010; Zou et al., 2006).
Once initial colonization and establishment have occurred, invasive species may spread from long- and short-distance dispersal. The rate of range expansion will obviously be influenced by propagule pressure and dispersal capacity but also by the ability of individuals to survive and reproduce in the new range where the invasive species may encounter novel selective regimes (Sakai et al., 2001). The evolution of such local adaptation requires genetic variation. Little is known about the genetic composition of $P$. corethrurus populations. Studies of population genetics might provide valuable information about the process of invasion, for instance by comparing the genetic composition of recently established populations with populations in the native range.

The last phase of the invasion process is the integration of the species in the ecosystem and its impact on the environment. The impact of $P$. corethrurus on soil physical structure may be either detrimental or beneficial. Depending on the SOM content, its activity may either promote soil compaction, especially when populations of other "decompacting" species are not present, or contribute to soil bioturbation (Hallaire et al., 2000). Moreover, P. corethrurus is known to accelerate biogeochemical fluxes (González et al., 2006). In particular, its casting activity may increase the $\mathrm{N}$ and $\mathrm{P}$ availability in agroecosystems. $P$. corethrurus presence may thus be beneficial for plant growth. Teng et al. (2016) also demonstrated its positive effect on plant health.

The impact of $P$. corethrurus on other earthworm species and in particular on native species is still an open question. Some studies have stated that an increase in densities of $P$. corethrurus might directly cause the disappearance of native species and that once established in areas inhabited by native species, its effects on soil properties prevent the recolonization by native species populations (Fragoso et al., 1995; Lapied and Lavelle, 2003). However, P. corethrurus has been observed in coexistence with native species in some disturbed sites (Table 2). These observations suggest the absence of competitive exclusion as proposed by Marichal et al. (2010).

The literature about biotic interactions with $P$. corethrurus is almost exclusively about earthworm/earthworm and plant/earthworm interactions except for a few studies on nematodes. Information about the interaction between $P$. corethrurus and other soil macrofauna species is lacking. For instance, $P$. corethrurus has been observed in termite galleries (Gates, 1972) but, to our knowledge, no studies on their interactions have been carried out. Moreover, almost no data exist on parasites, pathogens and predators of this species, though such information could improve our understanding of $P$. corethrurus invasiveness.

\subsection{Evidence of cryptic diversity?}

Moreno (2004) mentioned the possibility that studies interested in $P$. corethrurus could have mistakenly studied other species in the same genus. Although several complexes of cryptic species have been recently described in earthworms, highlighting the difficulties of morphological diagnosis in this taxon (King et al., 2008; Novo et al., 2010; Pérez-Losada et al., 2009; Shekhovtsov et al., 2016), there is not much data available in the literature on the genetic diversity within the $P$. corethrurus morphospecies (Cunha et al., 2014; Dupont et al., 2012). In three populations of $P$. corethrurus in the Azores archipelago, Cunha et al. (2014) revealed the existence of two genetically divergent lineages which were morphologically indistinguishable. They showed that one of the lineages was able to cope with the extreme conditions found in the caldera of a volcano where it tolerates a mixture of nonanthropogenic chemical and physical stressors. This lineage could correspond to a new species and, in this case, the adaptation to the caldera environmental conditions cannot be interpreted as the sign of plasticity of $P$. corethrurus but instead as the result of a speciation process. This example illustrates that cryptic species may be different in their biological and ecological features and preferences (Birky et al., 2010). Thus, it is conceivable that the variable impacts of $P$. corethrurus on the environment, such as its compacting and de-compacting effects, 
are evidence of two different species. In this particular case, it seems however that opposite effects are most likely due to soil characteristics. Diaz Cosin et al. (2011) highlighted that comparing published data dealing with species belonging to a complex of cryptic species is dangerous, as the authors could have incorrectly identified the species. They recommended that authors deposit the individuals used in the experiments into a collection in order to eliminate this uncertainty.

By comparing $P$. corethrurus description in different published papers (Table 1), some morphological variability was observed. Further studies are now needed in order to determine if this variability could be explained by the existence of several cryptic species (e.g., James et al., 2010). To test this hypothesis, the concordance between morphological and phylogenetic identification of $P$. corethrurus should be tested in samples coming from its whole distribution range. Moreover, investigations of the reproduction mode and ploidy level of the different lineages would help to test two alternative hypotheses concerning the observation of sexual characters in some $P$. corethrurus specimens: (i) some populations may be mixture of sexual and asexual lineages and (ii) a unique lineage may have a mixed reproductive strategy allowing shifts from sexual to parthenogenetic reproduction according to the environmental conditions.

\section{Conclusion}

P. corethrurus is the most common and most studied tropical earthworm morphospecies; this review integrated both the most recent and earliest information on its biology and what makes it a successful invader. Its impacts on the environment and other soil organisms were found to be strongly influenced by soil characteristics as well as land use and management. Most of the studies that have been reviewed here have sampled the specimens in the introduced range of the species. Although in some parts of the world this morphospecies has probably reached the integration stage of the invasion process and has established strong biological interaction within ecosystems, in its more recently introduced ranges, $P$. corethrurus populations may not have reached this stage yet. Thus, throughout its distribution area and given the stage of the invasion process that has been reached, population dynamics may be different and studies of ecological processes may not be comparable.

\section{Acknowledgements}

The authors are grateful to the service of "prêt inter-bibliothèque" of the University Paris-Est Créteil and to George Brown and Raphael Marichal who helped to provide numerous full-texts of articles. The authors are also grateful to Patrick Lavelle for its stimulating comments and extensive reading of the manuscript and to Naoise Nunan for English language editing.

\section{References}

Alegre, J.C., Pashanasi, B., Lavelle, P., 1996. Dynamics of soil physical properties in Amazonian agroecosystems inoculated with earthworms. Soil Science Society of America Journal 60, 1522-1529.

Araujo, Y., Luizão, F.J., Barros, E., 2004. Effect of earthworm addition on soil nitrogen availability, microbial biomass and litter decomposition in mesocosms. Biology and Fertility of Soils 39, 146-152. http://dx.doi.org/10.1007/s00374-003-0696-0.

Arunachalam, S., 1987. Some aspects of the biology of a tropical earthworm Pontoscolex corethrurus (F. Muller). Bombay Natural History 75, 110-114.

Ayala, L.P., Barois, I., 2016. Development of the earthworm Pontoscolex corethrurus in soils amended with a peat-based plant growing medium. Applied Soil Ecology 104 131-137. http://dx.doi.org/10.1016/j.apsoil.2015.10.005.

Ayres, I., Guerra, R.T., 1981. Agua como fator limitante para minhocas. Acta Amazonica $11,78-86$.

Barois, I., 1992. Mucus production and microbial activity in the gut of two species of Amynthas (megascolecidae) from cold and warm tropical climates. Soil Biology and Biochemistry 24, 1507-1510. http://dx.doi.org/10.1016/0038-0717(92)90141-J.

Barois, I., Lavelle, P., 1986. Changes in respiration rate and some physiochemical properties of a tropical soil during transit through Pontoscolex corethrurus (Glossoscolecidae, Oligochaeta). Soil Biology and Biochemistry 18, 539-541.
Barois, I., Lavelle, P., Rossf, J.P., Bikram, K., Angeles, A., Fragoso, C., Jimenez, J.J., Decaëns, T., Kanyony, J., Blancharf, E., 1999. Ecology of Earthworm Species with Large Environmental Tolerance and/or Extended Distributions. Earthworm Management in Tropical Agroecosystems CABI. pp. 57-85 ISBN 0-85199-270-6.

Barros, E., Curmi, P., Hallaire, V., Chauvel, A., Lavelle, P., 2001. The role of macrofauna in the transformation and reversibility of soil structure of an oxisol in the process of forest to pasture conversion. Geoderma 100, 193-213. http://dx.doi.org/10.1016/ S0016-7061(00)00086-0.

Beddard, F., 1893. Two New Genera and Some New Species of Earthworms. pp. 243-280. http://dx.doi.org/10.4039/Ent49193-6.

Bernard, L., Chapuis-Lardy, L., Razafimbelo, T., Razafindrakoto, M., Pablo, A.-L., Legname, E., Poulain, J., Brüls, T., O'Donohue, M., Brauman, A., Chotte, J.-L., Blanchart, E., 2012. Endogeic earthworms shape bacterial functional communities and affect organic matter mineralization in a tropical soil. International Society for Microbial Ecology 6, 213-222. http://dx.doi.org/10.1038/ismej.2011.87.

Bhattacharjee, G., Chaudhuri, P.S., 2002. Cocoon production, morphology, hatching pattern and fecundity in seven tropical earthworm species - a laboratory-based investigation. Journal of Biosciences 27, 283-294. http://dx.doi.org/10.1007/ BF02704917.

Birky, C.W., Adams, J., Gemmel, M., Perry, J., 2010. Using population genetic theory and DNA sequences for species detection and identification in asexual organisms. PLoS ONE 5 (5), e10609. https://doi.org/10.1371/journal.pone.0010609.

Blakemore, R.J., 2012. In: Cosmopolitan Earthworms, fifth ed. Yokohama.

Blakemore, R.J., 2006. In: Cosmopolitan Earthworms - an Eco-taxonomic Guide to the Peregrine Species of the World, second ed. VermEcology, Japan $600+150$ figs.

Blanchart, E., Lavelle, P., Braudeau, E., Le bissonnais, Y., Valentins, C., 1997. Regulation of soil structure by geophagous earthworm activities in humid savannas of Cote d'Ivoire. Soil Biol. Biochem 29, 431-439.

Blouin, M., Hodson, M.E., Delgado, E.A., Baker, G., Brussaard, L., Butt, K.R., Dai, J., Dendooven, L., Peres, G., Tondoh, J.E., Cluzeau, D., Brun, J.J., 2013. A review of earthworm impact on soil function and ecosystem services. European Journal of Soil Science 64, 161-182. http://dx.doi.org/10.1111/ejss.12025.

Blouin, M., Zuily-Fodil, Y., Pham-Thi, A.T., Laffray, D., Reversat, G., Pando, A., Tondoh, J., Lavelle, P., 2005. Belowground organism activities affect plant aboveground phenotype, inducing plant tolerance to parasites. Ecology Letters 8, 202-208. http:// dx.doi.org/10.1111/j.1461-0248.2004.00711.x.

Borges, S., Alfaro, M., Maldonado, S., Santiago, A., 2006. A first survey of the earthworms of Bosque del Pueblo, Puerto Rico. Caribbean Journal of Science 42, 366-370.

Boyer, J., Reversat, G., Lavelle, P., Chabanne, A., 2013. Interactions between earthworms and plant-parasitic nematodes. European Journal of Soil Biology 59, 43-47. http:// dx.doi.org/10.1016/j.ejsobi.2013.10.004.

Brown, G.G., James, S.W., Pasini, A., Nunes, D.H., Benito, N.P., Martins, P.T., Sautter, K.D., 2006. Exotic, peregrine, and invasive earthworms in Brazil: diversity, distribution, and effects on soils and plants. Caribbean Journal of Science 42, 339-358.

Brown, G., Pashanasi, B., Villenave, C., Patron, J.C., Senapati, B.K., Giri, S., Barois, I., Lavelle, P., Blanchart, E., Blakemore, R.J., Spain, A.V., Boyer, J., 1999. Effects of earthworms on plant production in the tropics. In: Lavelle, P., Brussaard, L., Hendrix, P. (Eds.), Earthworm Management in Tropical Agroecosystems. CABI publishing, Wallingford, pp. 87-137.

Buch, A.C., Brown, G.G., Correia, M.E.F., Silva-filho, F.L.E.V., 2017. Ecotoxicology of mercury in tropical forest soils: impact on earthworms. Science of the Total Environment 589, 222-231. http://dx.doi.org/10.1016/j.scitotenv.2017.02.150.

Buch, A.C., Brown, G.G., Niva, C.C., Sautter, K.D., Sousa, J.P., 2013. Toxicity of three pesticides commonly used in Brazil to Pontoscolex corethrurus (Müller, 1857) and Eisenia andrei (Bouché, 1972). Applied Soil Ecology 69, 32-38. http://dx.doi.org/10. 1016/j.apsoil.2012.12.011.

Bufford, J., Daehler, C., 2011. Life history strategies. In: Encyclopedia of Biological Invasions. University of California Press, Berkeley Los Angeles London, pp. 437-442. Chapuis-Lardy, L., Brauman, a., Bernard, L., Pablo, a. L., Toucet, J., Mano, M.J., Weber, L., Brunet, D., Razafimbelo, T., Chotte, J.L., Blanchart, E., 2010. Effect of the endogeic earthworm Pontoscolex corethrurus on the microbial structure and activity related to $\mathrm{CO}_{2}$ and $\mathrm{N}_{2} \mathrm{O}$ fluxes from a tropical soil (Madagascar). Applied Soil Ecology 45, 201-208. http://dx.doi.org/10.1016/j.apsoil.2010.04.006.

Chapuis-Lardy, L., Brossard, M., Lavelle, P., Schouller, E., 1998. Phosphorus transformations in a ferralsol through ingestion by Pontoscolex corethrurus, a geophagous earthworm. European Journal of Soil Biology 34, 61-67. http://dx.doi.org/10.1016/ S1164-5563(99)90002-X.

Chapuis-Lardy, L., Ramiandrisoa, R.S., Randriamanantsoa, L., Morel, C., Rabeharisoa, L., Blanchart, E., 2009. Modification of P availability by endogeic earthworms (Glossoscolecidae) in ferralsols of the Malagasy highlands. Biology and Fertility of Soils 45, 415-422. http://dx.doi.org/10.1007/s00374-008-0350-y.

Chapuis-Lardy, L., Brossard, M., 1995. Phosphorus transformations and stability in a Ferralsol ingested by a geophagous earthworm. Comptes Rendus De L'Academie Des Sciences Serie Ii 320, 587-592.

Chaudhuri, P.S., Nath1, S., Paliwal, R., 2008. Earthworm population of rubber plantations ( Hevea brasiliensis ) in Tripura, India. Tropical Ecology 49, 225-234.

Chaudhuri, P.S., Bhattacharjee, S., 2011. Reproductive biology of eight tropical earthworm species of rubber plantations in Tripura, India. Tropical Ecology 52, 49-60.

Chaudhuri, P.S., Nath, S., 2011. Community structure of earthworms under rubber plantations and mixed forests in Tripura, India. Journal of Environmental Biology 32, 537-541.

Chaudhuri, P.S., Pal, T.K., Nath, S., Dey, S.K., 2012. Effects of five earthworm species on some physico-chemical properties of soil. Journal of Environmental Biology/ Academy of Environmental Biology, India 33, 713-716.

Chauvel, A., Grimald, M., Barros, E., Blanchart, E., Desjardins, T., Sarrazin, M., Lavelle, P., 1999. Pasture damage by an Amazonian earthworm. Nature 398, 32-33. 
Chuang, S.C., Lee, H., Chen, J.H., 2004. Diurnal rhythm and effect of temperature on oxygen consumption in earthworms, Amynthas gracilis and Pontoscolex corethrurus. Journal of Experimental Zoology. a, Comparative Experimental Biology 301, 737-744. http://dx.doi.org/10.1002/jez.a.96.

Coq, S., Barthès, B.G., Oliver, R., Rabary, B., Blanchart, E., 2007. Earthworm activity affects soil aggregation and organic matter dynamics according to the quality and localization of crop residues - an experimental study (Madagascar). Soil Biology and Biochemistry 39, 2119-2128. http://dx.doi.org/10.1016/j.soilbio.2007.03.019.

Csuzdi, C., 2012. Earthworm species, a searchable database. Opuscula Zoologica Budapest 43, 97-99.

Cunha, L., Montiel, R., Novo, M., Orozco-terWengel, P., Rodrigues, a, Morgan, a J., Kille, P., 2014. Living on a volcano's edge: genetic isolation of an extremophile terrestrial metazoan. Heredity 112, 132-142. http://dx.doi.org/10.1038/hdy.2013.84.

Da Silva, E., Nahmani, J., Lapied, E., Alphonse, V., Garnier-Zarli, E., Bousserrhine, N., 2016. Toxicity of mercury to the earthworm Pontoscolex corethrurus in a tropical soil of French Guiana. Applied Soil Ecology 104, 79-84. http://dx.doi.org/10.1016/j apsoil.2015.11.018.

Desjardins, T., Charpentier, F., Pashanasi, B., Pando-Bahuon, A., Lavelle, P., Mariotti, A., 2003. Effects of earthworm inoculation on soil organic matter dynamics of a cultivated ultisol. Pedobiologia 47, 835-841. http://dx.doi.org/10.1078/0031-405600268.

Dey, A., Chaudhuri, P.S., 2014. Earthworm community structure of pineapple (Ananas comosus) plantations under monoculture and mixed culture in West Tripura, India. Tropical Ecology 55, 1-17.

Diaz Cosin, D.J., Novo, M., Fernandez, R., 2011. Reproduction of earthworms: sexual selection and parthenogenesis, in: biology of earthworms. Soil Biology 69-86. http:// dx.doi.org/10.1007/978-3-642-14636-7.

Drake, H.L., Horn, M. a, 2007. As the worm turns: the earthworm gut as a transient habitat for soil microbial biomes. Annual Review of Microbiology 61, 169-189. http://dx.doi.org/10.1146/annurev.micro.61.080706.093139.

Duarte, A.P., Melo, V.F., Brown, G.G., Pauletti, V., 2014. Earthworm (Pontoscolex corethrurus) survival and impacts on properties of soils from a lead mining site in Southern Brazil. Biology and Fertility of Soils 50, 851-860. http://dx.doi.org/10. 1007/s00374-014-0906-y.

Duarte, A.P., Melo, V.F., Brown, G.G., Pauletti, V., 2012. Changes in the forms of lead and manganese in soils by passage through the gut of the tropical endogeic earthworm (Pontoscolex corethrurus). European Journal of Soil Biology 53, 32-39. http://dx.doi. org/10.1016/j.ejsobi.2012.08.004.

Dupont, L., Viard, F., David, P., Bishop, J., 2007. Combined effects of bottlenecks and selfing in populations of Corella eumyota, a recently introduced sea squirt in the English Channel. Diversity and Distributions 13, 808-817.

Dupont, L., Decaëns, T., Lapied, E., Chassany, V., Marichal, R., Dubs, F., Maillot, M., Roy, V., 2012. Genetic signature of accidental transfer of the peregrine earthworm Pontoscolex corethrurus (Clitellata, Glossoscolecidae) in French Guiana. European Journal of Soil Biology 53, 70-75. http://dx.doi.org/10.1016/j.ejsobi.2012.09.001.

Dybdahl, M.F., Drown, D.M., 2011. The absence of genotypic diversity in a successful parthenogenetic invader. Biological Invasions 13, 1663-1672. http://dx.doi.org/10. 1007/s10530-010-9923-4.

Eisen, G.A., 1896. Pontoscolex Lilljeborgi with Notes on Auditory Sense Cells of Pontoscolex Corethrurus. pp. 1-16.

Eisenhauer, N., Schlaghamerský, J., Reich, P.B., Frelich, L.E., 2011. The wave towards a new steady state: effects of earthworm invasion on soil microbial functions. Biological Invasions 13, 2191-2196. http://dx.doi.org/10.1007/s10530-011-0053-4.

Elton, C.S., 1958. The Ecology of Invasions by Animals and Plants. Methuen, London.

Fonte, S.J., Barrios, E., Six, J., 2010. Earthworm impacts on soil organic matter and fertilizer dynamics in tropical hillside agroecosystems of Honduras. Pedobiologia 53, 327-335. http://dx.doi.org/10.1016/j.pedobi.2010.03.002.

Fonte, S.J., Quintero, D.C., Velásquez, E., Lavelle, P., 2012. Interactive effects of plants and earthworms on the physical stabilization of soil organic matter in aggregates. Plant and Soil 359, 205-214. http://dx.doi.org/10.1007/s11104-012-1199-2.

Fonte, S.J., Six, J., 2010. Earthworms and litter management contributions to ecosystem services in a tropical agroforestry system. Ecological Applications 20, 1061-1073. http://dx.doi.org/10.1890/09-0795.1.

Forster, B., García, M., Francimari, O., Rombke, J., 2006. Effects of carbendazim and lambda-cyhalothrin on soil invertebrates and leaf litter decomposition in semi-field and field tests under tropical conditions (Amazonia, Brazil). European Journal of Soil Biology 42, S171-S179. http://dx.doi.org/10.1016/j.ejsobi.2006.07.011.

Fragoso, C., Brown, G.G., Patrón, J.C., Blanchart, E., Lavelle, P., Pashanasi, B., Senapati, B., Kumar, T., 1997. Agricultural intensification, soil biodiversity and agroecosystem function in the tropics: the role of decomposer biota. Applied Soil Ecology 6, 17-35.

Fragoso, C., James, S., Borges, S., 1995. In: Hendrix, P. (Ed.), Native Earthworms of the North Neotropical Region: Current Status and Controversies. Earthworm Ecology and Biogeography in North America. Lewis Publishers, Boca Raton, pp. 67-115.

Fragoso, C., Kanyonyo, J., Moreno, A., Senapati, B.K., Blanchart, E., 1999. A survey of tropical earthworms: taxonomy, biogeography and environmental plasticity. Earthworm Management in Tropical Agroecosystems CAB Intern 1-26.

Fragoso, C., Lozano, N., 1992. Resource allocation strategies imposed by caudal amputation and soil moisture in the tropical earthworm Pontoscolex corethrurus. Soil Biology and Biochemistry 24, 1237-1240.

Ganihar, S.R., 2003. Nutrient mineralization and leaf litter preference by the earthworm Pontoscolex corethrurus on iron ore mine wastes. Restoration Ecology 11, 475-482. http://dx.doi.org/10.1046/j.1526-100X.2003.rec0253.x.

García-Pérez, J.A., Alarcón-Gutiérrez, E., Perroni, Y., Barois, I., 2014. Earthworm communities and soil properties in shaded coffee plantations with and without application of glyphosate. Applied Soil Ecology 83, 230-237. http://dx.doi.org/10.1016/j. apsoil.2013.09.006.
García-pérez, J.A., Alarcón, E., Hernández, Y., Hernández, C., 2016. Impact of litter contaminated with glyphosate-based herbicide on the performance of Pontoscolex corethrurus, soil phosphatase activities and soil pH. Applied Soil Ecology 104, 31-41. http://dx.doi.org/10.1016/j.apsoil.2016.03.007.

García, J.A., Fragoso, C., 2002. Growth, reproduction and activity of earthworms in degraded and amended tropical open mined soils: laboratory assays. Applied Soil Ecology 20, 43-56. http://dx.doi.org/10.1016/S0929-1393(02)00009-4.

García, J., Fragoso, C., 2003. Influence of different food substrates on growth and reproduction of two tropical earthworm species (Pontoscolex corethrurus and Amynthas corticis) the 7th international symposium on earthworm ecology $\cdot$ Cardiff $\cdot$ Wales 2002. Pedobiologia 47, 754-763. http://dx.doi.org/10.1016/S0031-4056(04) 70264-4.

Gates, G.E., 1973. Contributions to north American earthwors (Annelida) No. 6 contributions to a revision ofthe earthworm family Glossoscolecidae. I. Pontoscolex corethrurus (MüIler, 1857). Bulletin of Tall Timbers Research Station No. 14, 1-12.

Gates, G.E., 1972. Burmese earthworms: an introduction to the systematics and biology of megadrile oligochaetes with special reference to Southeast Asia. Transactions of the American Philosophical Society 62 (7), 1-326.

González, G., Huang, C.Y., Zou, X., Rodríguez, C., 2006. Earthworm invasions in the tropics. Biological Invasions Belowground: Earthworms As Invasive Species 8, 1247-1256. http://dx.doi.org/10.1007/978-1-4020-5429-7 6.

González, G., García, E., Cruz, V., Borges, S., Zalamea, M., Rivera, M.M., 2007. Earthworm communities along an elevation gradient in Northeastern Puerto Rico. European Journal of Soil Biology 43, S24-S32. http://dx.doi.org/10.1016/j.ejsobi. 2007.08.044.

González, G., Zou, X., Borges, S., 1996. Earthworm abundance and species composition in abandoned tropical crop lands comparisons of tree plantations and secondary forests. Pedobiologia 40, 385-391.

González, G., Zou, X., Sabat, A., Fetcher, N., 1999. Earthworm abundance and distribution pattern in contrasting plant communities within a tropical wet forest in Puerto Rico. Caribbean Journal of Science 35, 93-100.

González, G., Zou, X.M., 1999. Earthworm influence on N availability and the growth of Cecropia schreberiana in tropical pasture and forest soils. Pedobiologia 43, 824-829.

Guerra, R.T., 1994. Earthworm activity in forest and savanna soils. Acta Amazonica 24, 303-308.

Hallaire, V., Curmi, P., Duboisset, A., Lavelle, P., Pashanasi, B., 2000. Soil structure changes induced by the tropical earthworm Pontoscolex corethrurus and organic inputs in a Peruvian ultisol. European Journal of Soil Biology 36, 35-44. http://dx.doi. org/10.1016/S1164-5563(00)01048-7.

Hamoui, H., 1991. Life-cycle and growth of Pontoscolex corethrurus (Müller, 1857) (Oligochaeta, Glossoscolecidae) in the laboratory. Revue d'Ecologie et de Biologie Du Sol 28, 469-478.

Hendrix, P., Lachnicht, S., Callaham, M., Zou, X., 1999. Stable isotopic studies of earthworm feeding ecology in tropical ecosystems of Puerto Rico. Rapid Communications in Mass Spectrometry :RCM 13, 1295-1299. http://dx.doi.org/10.1002/(SICI)1097.

Hendrix, P.F., Callaham, M.A., Drake, J.M., Huang, C.-Y., James, S.W., Snyder, B.A. Zhang, W., 2008. Pandora's box contained bait: the Global problem of introduced earthworms. Annual Review of Ecology, Evolution, and Systematics 39, 593-613. http://dx.doi.org/10.1146/annurev.ecolsys.39.110707.173426.

Henrot, J., Brussaard, L., 1997. Abundance, casting activity, and cast quality of earthworms in an acid Ultisol under alley-cropping in the humid tropics. Applied Soil Ecology 6, 169-179. http://dx.doi.org/10.1016/S0929-1393(97)00007-3.

Hernández-Castellanos, B., Zavala-Cruz, J., Martinez-Hernandez, S., Dendooven, L., Contreras-Ramos, S.M., Noa-Carrazana, J.C., Fragoso, C., Ortiz-Ceballos, A.I., 2013. Earthworm populations in an aged hydrocarbon contaminated soil. Environmental Sciences 7, 27-37.

Hua, Z., XiaoDong, Y., Jie, D., YiXue, W., 2008. Influence of soil temperature and moisture on the cocoon production and hatching of the exotic earthworm Pontoscolex corethrurus. Zoological Research 29, 305-312.

Huang, J., Zhang, W., Liu, M., Briones, M.J.I., Eisenhauer, N., Shao, Y., Cai, X., Fu, S., Xia, H., 2015. Different impacts of native and exotic earthworms on rhizodeposit carbon sequestration in a subtropical soil. Soil Biology and Biochemistry 90, 152-160. http://dx.doi.org/10.1016/j.soilbio.2015.08.011.

Hubers, H., Borges, S., Alfaro, M., 2003. The oligochaetofauna of the nipe soils in the maricao state forest, Puerto Rico. Pedobiologia 47, 475-478. http://dx.doi.org/10 1016/S0031-4056(04)70225-5.

Huerta, E., Rodriguez-olan, J., Evia-castillo, I., Montejo-meneses, E., Cruz-mondragon, M. De, Garcia-hernandez, R., Uribe, S., 2007. Earthworms and soil properties in Tabasco, Mexico. European Journal of Soil Biology 43, 190-195. http://dx.doi.org/10.1016/j. ejsobi.2007.08.024.

James, S.W., Porco, D., Decaëns, T., Richard, B., Rougerie, R., Erséus, C., 2010. DNA barcoding reveals cryptic diversity in Lumbricus terrestris L., 1758 (Clitellata): resurrection of L. herculeus (Savigny, 1826). PLoS ONE 5 (12). http://dx.doi.org/10. 1371/journal.pone.0015629.

Jiménez, J.J., Cepeda, A., Decaëns, T., Oberson, A., Friesen, D.K., 2003. Phosphorus fractions and dynamics in surface earthworm casts under native and improved grasslands in a Colombian savanna Oxisol. Soil Biology and Biochemistry 35, 715-727. http://dx.doi.org/10.1016/S0038-0717(03)00090-7.

Jusselme, M.D., Poly, F., Lebeau, T., Rouland-lefèvre, C., Miambi, E., 2015. Effects of earthworms on the fungal community and microbial activity in root-adhering soil of Lantana camara during phytoextraction of lead. Applied Soil Ecology 96, 151-158. http://dx.doi.org/10.1016/j.apsoil.2015.07.011.

Jusselme, M.D., Poly, F., Miambi, E., Mora, P., Blouin, M., Pando, A., Rouland-Lefèvre, C., 2012. Effect of earthworms on plant Lantana camara Pb-uptake and on bacterial communities in root-adhering soil. The Science of the Total Environment 416, 200-207. http://dx.doi.org/10.1016/j.scitotenv.2011.10.070. 
Kale, R.D., Krishnamoorthy, R.V., 1979. Pesticidal effects of Sevin n ( 1-naphthyl-n-methyl carbamate ) on the survivability and abundance of earthworm Pontoscolex corethrurus. Proceedings: Animal Sciences 88, 391-396.

King, R.A., Tibble, A.L., Symondson, W.O.C., 2008. Opening a can of worms: unprecedented sympatric cryptic diversity within British lumbricid earthworms. Molecular Ecology 17, 4684-4698. http://dx.doi.org/10.1111/j.1365-294X.2008. 03931.x.

Lachnicht, S., Hendrix, P., Zou, X., 2002. Interactive effects of native and exotic earthworms on resource use and nutrient mineralization in a tropical wet forest soil of Puerto Rico. Biology and Fertility of Soils 36, 43-52. http://dx.doi.org/10.1007/ s00374-002-0501-5.

Lafont, A., Risède, J.-M., Loranger-Merciris, G., Clermont-Dauphin, C., Dorel, M., Rhino, B., Lavelle, P., 2007. Effects of the earthworm Pontoscolex corethrurus on banana plants infected or not with the plant-parasitic nematode Radopholus similis. Pedobiologia 51, 311-318. http://dx.doi.org/10.1016/j.pedobi.2007.05.004.

Lapied, E., Lavelle, P., 2003. The peregrine earthworm Pontoscolex corethrurus in the East coast of Costa Rica. Pedobiologia 47, 471-474.

Lavelle, P., 1981. Stratégies de reproduction chez les Vers de terre. Acta Oecologica. Oecologia Generalis 117-133.

Lavelle, P., Barois, I., Cruz, I., Fragoso, C., Hernandez, A., Pineda, A., Rangel, P., 1987. Adaptive strategies of Pontoscolex corethrurus (Glossoscolecidae, Oligochaeta), a peregrine geophagous earthworm of the humid tropics. Biology and Fertility of Soils 5, 188-194. http://dx.doi.org/10.1007/BF00256899.

Lavelle, P., Bignell, D., Lepage, M., Wolters, W., Roger, P., Ineson, P., Heal, O.W., Dhillion, S., 1997. Soil function in a changing world: the role of invertebrate ecosystem engineers. European Journal of Soil Biology 33, 159-193.

Lavelle, P., Martin, A., 1992. Small scale and large scale effects of endogenic earthworms on soil organic matter dynamics in soils of the humid tropics. Soil Biology \& Biochemistry 24, 1491-1498.

Lavelle, P., Melendez, G., Pashanasi, B., Schaefer, R., 1992. Nitrogen mineralization and reorganization in casts of the geophagous tropical earthworm Pontoscolex corethrurus (Glossoscolecidae). Biology and Fertility of Soils 14, 49-53. http://dx.doi.org/10. 1007/bf00336302.

Lavelle, P., Pashanasi, B., 1989. Soil macrofauna and land management in peruvian Amazonia (Yurimaguas, loreto). Pedobiologia 33, 283-291.

Lavelle, P., Pashanasi, B., Charpentier, F.C.G., Rossi, J.P., Derouard, L., André, J., Ponge, J.F., Bernier, N., 1998. Large-scale effect of earthworms on soil organic matter and nutrient dynamics. Earthworm Ecology 103-122.

Lavelle, P., Rangel, P., Kanyonyo, J., 1983. Intestinal mucus production by two species of tropical earthworms: millsonia lamtoiana (Megaloscolecidae) and Ponthoscolex corethrurus (Glossoscolecidae). New Trends in Soil Biology 405-410.

Lavelle, P., Spain, A., 2001. Soil Ecology Kluwer Academic Publishers, London., in: Soil Ecology Kluwer Academic Publishers, London.

León, Y., Zou, X., Borges, S., Ruan, H., 2003. Recovery of native earthworms in abandoned tropical pastures. Conservation Biology 17, 999-1006. http://dx.doi.org/10 1046/j.1523-1739.2003.02098.x.

León, Y.S., Zou, X., 2004. Plant influences on native and exotic earthworms during secondary succession in old tropical pastures. Pedobiologia 48, 215-226. http://dx.doi. org $/ 10.1016 /$ j.pedobi.2003.12.006.

Li, Y., Shimabukuro-Madden, A., Mathews, B.W., 2010. The effects of tree plantation rotation on earthworm abundance and biomass in Hawaii. Applied Soil Ecology 46, 151-154. http://dx.doi.org/10.1016/j.apsoil.2010.07.003.

Liang, S.H., Chen, S.C., Chen, C.Y., Kao, C.M., Yang, J.I., Shieh, B.S., Chen, J.H., Chen, C.C., 2011. Cadmium-induced earthworm metallothionein-2 is associated with metal accumulation and counteracts oxidative stress. Pedobiologia 54, 333-340. http://dx. doi.org/10.1016/j.pedobi.2011.07.011.

Liu, A.Z.G., Zou, X.M., 2002. Exotic earthworms accelerate plant litter decomposition in a Puerto rican pasture and a wet forest. Ecological Society of America 12, 1406-1417.

Lopez-Hernandez, D., Lavelle, P., Fardeau, J.C., Niao, M., 1993. Phosphorus transformations in two P-sorption contrasting tropical soils during transit through Pontoscolex corethrurus (Glossoscolecidae: Oligochaeta). Soil Biology and Biochemistry 25, 789-792. http://dx.doi.org/10.1016/0038-0717(93)90124-T.

Loranger-Merciris, G., Cabidoche, Y.-M., Deloné, B., Quénéhervé, P., Ozier-Lafontaine, H., 2012. How earthworm activities affect banana plant response to nematodes parasitism. Applied Soil Ecology 52, 1-8. http://dx.doi.org/10.1016/j.apsoil.2011.10. 003

Marichal, R., Martinez, A.F., Praxedes, C., Ruiz, D., Carvajal, A.F., Oszwald, J., del Pilar Hurtado, M., Brown, G.G., Grimaldi, M., Desjardins, T., Sarrazin, M., Decaëns, T., Velasquez, E., Lavelle, P., 2010. Invasion of Pontoscolex corethrurus (Glossoscolecidae, Oligochaeta) in landscapes of the Amazonian deforestation arc. Applied Soil Ecology 46, 443-449. http://dx.doi.org/10.1016/j.apsoil.2010.09.001.

Marichal, R., Mathieu, J., Couteaux, M.M., Mora, P., Roy, J., Lavelle, P., 2011. Earthworm and microbe response to litter and soils of tropical forest plantations with contrasting C: N:P stoichiometric ratios. Soil Biology and Biochemistry 43, 1528-1535. http://dx. doi.org/10.1016/j.soilbio.2011.04.001.

Marichal, R., Grimaldi, M., Mathieu, J., Brown, G.G., Desjardins, T., Da Silva Jr., M.L., Praxedes, C., Martins, M.B., Velasquez, E., Lavelle, P., 2012. Is invasion of deforested Amazonia by the earthworm Pontoscolex corethrurus driven by soil texture and chemical properties? Pedobiologia 55, 233-240. http://dx.doi.org/10.1016/j.pedobi. 2012.03.006

Martinez, M.A., Sanchez, J.A., 2000. Comunidas de lombrices de tierra (Annelida: Oligochaeta) et un bosque siempre verde y un pastizal de sierra del rosario, Cuba. Caribbean Journal of Science 36, 94-103.

Mba, C.C., 1994. Rock phosphate solubilizing and cellulolytic actinomycete isolates of earthworm casts. Environmental Management 18, 257-261. http://dx.doi.org/10. 1007/BF02393766.
Mitchell, C.E., Agrawal, A.A., Bever, J.D., Gilbert, G.S., Hufbauer, R.A., Klironomos, J.N., Maron, J.L., Morris, W.F., Parker, I.M., Power, A.G., Seabloom, E.W., Torchin, M.E., Vázquez, D.P., 2006. Biotic interactions and plant invasions. Ecol. Lett. 9, 726-740.

Molina-Murguia, J.F.F., Garcia-Calderon, N.E., Martin, G.A., 2009. Cocoa industrial debris composting in soil and earthworm breeding. Compost Science \& Utilization 17, 197-204.

Moreno, A.G., 2004. ¿Quién es Pontoscolex (Pontoscolex) corethrurus (Müller, 1857) (Annelida, Glossoscolecidae)? In: Moreno y, A.G., Borges, S. (Eds.), Avances en Taxonomía de Lombrices de Tierra (Annelida, Oligochaeta). Ed. Complutense, pp. $59-70$.

Müller, F., 1857. Description of a new species of earthworm (Lumbricus corethrurus). Annual Magazine of Natural History 2, 13-15.

Nair, K., Manazhy, J., MAnazhy, A., Reynolds, J.W., 2009. Biology of cocoons of five species of earthworms (Annelida: Oligochaeta) from Kerala, India. Megadrilogica $13(1)$

Narayanan, P., Sathrumithra, S., Chistopher, G., Thomas, A.P., Hills, P., Julka, J.M., Pradesh, H., 2016. Current distribution of the invasive earthworm Pontoscolex corethrurus (Müller, 1857) after a century of its first report from Kerala state, India. Opuscula Zoologica Budapest 47, 101-107.

Nath, S., Chaudhuri, P.S., 2012. Effect of rubber leaf litter diet on growth and reproduction of five tropical species of earthworms under laboratory conditions. Journal of Applied Bioscience 38, 174-178.

Novo, M., Almodóvar, A., Fernández, R., Trigo, D., Díaz Cosín, D.J., 2010. Cryptic speciation of hormogastrid earthworms revealed by mitochondrial and nuclear data. Molecular Phylogenetics and Evolution 56, 507-512. http://dx.doi.org/10.1016/j. ympev.2010.04.010.

Nunes, D.H., Pasini, A., Benito, N.P., Brown, George G., 2006. Earthworm diversity in four land use systems in the region of Jaguapitã, paraná state, Brazil. Caribbean Journal of Science 42, 331-338.

Nxele, T.C., 2012. The megadrile fauna (Annelida: Oligochaeta) of queen Elizabeth Park, South Africa: species composition and distribution within different vegetation types. African Invertebrates 53 (2), 543-558. http://dx.doi.org/10.5733/afin.053.0207.

OECD, 1984. Earthworm Acute Toxicity Test. Organization for Economic Co-operation and Development.

Ortiz-ceballos, A.I., Hernández-garcía, M.C., Galindo-Gonzalez, J., 2009. Nest and feeding chamber construction for cocoon incubation in the tropical earthworm: Pontoscolex corethrurus. Dynamic Soil, Dynamic Plant 115-118 Special Issue 3.

Ortiz-gamino, D., Pérez-rodríguez, P., Ortiz-ceballos, A.I., 2016. Invasion of the tropica earthworm Pontoscolex corethrurus (Rhinodrilidae, Oligochaeta) in temperate grasslands. PeerJ Preprints 1-20, e2572. http://dx.doi.org/10.7717/peerj.2572.

Pashanasi, B., Lavelle, P., Alegre, J., Charpentier, F., 1996. Effect of the endogeic earthworm Pontoscolex corethrurus on soil chemical characteristics and plant growth in a low-input tropical agroecosystem. Soil Biology and Biochemistry 28, 801-810. http://dx.doi.org/10.1016/0038-0717(96)00018-1.

Pashanasi, B., Lavelle, P., Melendez, G., Szott, L., 1992. Effect of inoculation with the endogeic earthworm Pontoscolex corethrurus on $\mathrm{N}$ availability, soil microbial biomass and the growth of three tropical fruit tree seddlings in a pot experiment. Soil Biology and Biochemistry 24, 1655-1659.

Pauli, N., Barrios, E., Oberthür, T., Conacher, A., Ayarza, M., Welchez, L.A., 2005. The effects of the quesungual agroforestry system of western Honduras on soil macrofauna. Sociedade \& Natureza, Uberlândia (Special Issue), 466-477.

Paz-Ferreiro, J., Fu, S., Méndez, A., Gascó, G., 2014. Interactive effects of biochar and the earthworm Pontoscolex corethrurus on plant productivity and soil enzyme activities. Journal of Soils and Sediments 14, 483-494. http://dx.doi.org/10.1007/s11368-0130806-z.

Paz-Ferreiro, J., Liang, C., Fu, S., Mendez, A., Gasco, G., 2015. The effect of biochar and its interaction with the earthworm Pontoscolex corethrurus on soil microbial community structure in tropical soils. PLoS ONE 10, 1-11. http://dx.doi.org/10.1371/ journal.pone.0124891.

Pelosi, C., Barot, S., Capowiez, Y., Hedde, M., Vandenbulcke, F., 2014. Pesticides and earthworms. A review. Agronomy for Sustainable Development 34, 199-228. http:// dx.doi.org/10.1007/s13593-013-0151-z.

Pérez-Losada, M., Ricoy, M., Marshall, J.C., Domniguez, J., 2009. Phylogenetic assessment of the earthworm Aporrectodea caliginosa species complex (Oligochaeta: Lumbricidae) based on mitochondrial and nuclear DNA sequences. Molecular Phylogenetics and Evolution 52, 293-302. http://dx.doi.org/10.1016/j.ympev.2009. 04.003.

Plisko, J., 2001. Notes on the occurrence of the introduced earthworm Pontoscolex core thrurus (Müller, 1857) in South Africa (Oligochaeta: Glossoscolecidae ). African Invertebrates 42, 323-334.

Ponge, J.F., Topoliantz, S., Ballof, S., Rossi, J.-P., Lavelle, P., Betsch, J.-M., Gaucher, P., 2006. Ingestion of charcoal by the Amazonian earthworm Pontoscolex corethrurus: a potential for tropical soil fertility. Soil Biology and Biochemistry 38, 2008-2009. https://doi.org/10.1016/j.soilbio.2005.12.024.

Ressetti, R.R., 2006. Abundance, biomass and species of earthworm in ecosystems of urban areas. Scientia Agraria 7, 61-66.

Reynolds, J.W., Jones, A.G., 2006. The earthworms (Oligochaeta: acanthodrilidae, Glossoscolecidae, and Lumbricidae) of the Falkland Islands, South Atlantic ocean. Megadrilogica 10, 75-86.

Ribeiro, F., Elvira, Æ.B., Moyle, P.B., 2008. Life-history traits of non-native fishes in Iberian watersheds across several invasion stages: a first approach. Biological Invasions 10, 89-102. http://dx.doi.org/10.1007/s10530-007-9112-2.

Righi, G., 1984. Pontoscolex (Oligochaeta, Glossoscolecidae), a new evaluation. Stud. Neotrop. Fauna Environ 19, 159-177.

Righi, G., 1990. Minhocas de Mato Grosso e de Rondonia.

Righi, G., Bittencourt, E.C.R., 1972. On the blood system of Pontoscolex corethrurus 
(Fr.Muller 1857) (Oligochaeta Glossoscolecidae). Monitore Zoologico Italiano Italian Journal of Zoology 6 .

Römbke, J., García, M., 2000. Assessment of Ecotoxicological effects of pesticides on the soil fauna and soil processes under tropical conditions. Proceeding of German-brazilian 1999, 543-549.

Römbke, J., Schmidt, P., Höfer, H., 2009. The earthworm fauna of regenerating forests and anthropogenic habitats in the coastal region of Paraná. Pesquisa Agropecuária Brasileira 44, 1040-1049. http://dx.doi.org/10.1590/S0100-204X2009000800037.

Sabrina, D.T., Hanafi, M.M., Gandahi, A.W., Mahmud, T.M.M., Nor Azwady, A.A., 2013. Effect of mixed organic-inorganic fertilizer on growth and phosphorus uptake of setaria grass (Setaria splendida). Australian Journal of Crop Science 7, 75-83.

Sakai, A.K., Allendorf, F.W., Holt, J.S., Lodge, M., Molofsky, J., With, K.A., Cabin, R.J., Cohen, J.E., Norman, C., Mccauley, D.E., Neil, P.O., Parker, M., Thompson, J.N., Weller, S.G., 2001. The population biology of invasive species. Annu. Rev. Ecol. Evol. Syst 32, 305-332.

Senapati, B.K., 1992. Biotic interactions between soil nematodes and earthworms. Soil Biol. Biochem. Soil Biology and Biochemistry 24 (12), 1441-1444.

Senapati, B.K., Lavelle, P., Giri, S., Pashanasi, B., Alegre, J., Decaëns, T., Jimenez, J.J., Albrecht, A., Blanchart, E., Mahieux, M., Rousseaux, L., Thomas, R., Panigrahi, P., Venkatachalam, M., 1999. In-soil earthworm technologies for tropical agroecosystems. In: Lavelle, P., Brussaard, L., Hendrix, P. (Eds.), The Management of Earthworms in Tropical Agroecosytems, pp. 189-227.

Shekhovtsov, S.V., Golovanova, E.V., Peltek, S.E., 2016. Different dispersal histories of lineages of the earthworm Aporrectodea caliginosa (Lumbricidae, Annelida) in the Palearctic. Biological Invasions 18, 751-761. http://dx.doi.org/10.1007/s10530015-1045-6.

Shen, H., Yeo, D., 2005. Terrestrial earthworms (Oligochaeta) from Singapore. The Raffles Bulletin of Zoology 53, 13-33.

Shen, H.P., Tsai, C.F., Fang, Y.P., Chen, J.H., 2011. Parthenogenesis, polyploidy and reproductive seasonality in the Taiwanese mountain earthworm Amynthas catenus Tsai et al, 2001 (Oligochaeta, Megascolecidae). Pedobiologia 54, 133-139. http://dx.doi. org/10.1016/j.pedobi.2010.12.002.

Shilenkova, O.L., Tiunov, A.V., 2015. Assimilation of labile carbon and particulate organic matter by tropical endogeic earthworms Pontoscolex corethrurus (Glossoscolecidae, Oligochaeta). Biology Bulletin 42, 696-701. http://dx.doi.org/10. 1134/S1062359015080099.

Sierra, J., Loranger-Merciris, G., Desfontaines, L., Boval, M., 2014. Aerobic microbial activity in four tropical earthworm-soil systems. A mesocosm experiment. Soil Research 52, 584. http://dx.doi.org/10.1071/SR14034.

Simberloff, D., 2009. The role of propagule pressure in biological invasions. The Annual Review of Ecology 40, 81-102. http://dx.doi.org/10.1146/annurev.ecolsys.110308. 120304.

Sizmur, T., Hodson, M.E., 2009. Do earthworms impact metal mobility and availability in soil? Environmental Pollution 157, 1981-1989. http://dx.doi.org/10.1016/j.envpol. 2009.02.029.

Sol, D., Maspons, J., Vall-1losera, M., Bartomeus, I., García-Peña, G.E., Piñol, J., Freckleton, R.P., 2012. Unraveling the life history of successful invaders. Science 337. Somniyam, P., Suwanwaree, P., 2009. The diversity and distribution of terrestrial earthworms in Sakaerat Environmental Research Station and adjacent areas, Nakhon Ratchasima, Thailand. World Applied Sciences Journal 6, 221-226.

Spain, A.V., Saffigna, P.G., Woov, A.W., 1990. Tissue carbon sources for Pontoscolex corethrurus (Oligochaeta: Glossoscolecidae) in a sugarcane ecosystem. Soil Biology and Biochemistry 22, 703-706.

Sparovek, G., Lambais, M.R., Da Silva, A.P., Tormena, C.A., 1999. Earthworm (Pontoscolex corethrurus) and organic matter effects on the reclamation of an eroded oxisol. Pedobiologia 43, 698-704.

Speratti, A.B., Whalen, J.K., 2008. Carbon dioxide and nitrous oxide fluxes from soil as influenced by anecic and endogeic earthworms. Applied Soil Ecology 38, 27-33.

Suárez, E.R., Fahey, T.J., Yavitt, J.B., Groffman, P.M., Bohlen, P.J., 2006. Patterns of litter disappearance in a northern hardwood forest invaded by exotic earthworms. Ecological Applications 16, 154-165. http://dx.doi.org/10.1890/04-0788.

Tapia-Coral, S.C., Luizao, F.J., Barros, E., Pashanasi, B., del Castillo, D., 2006. Effect of Pontoscolex corethrurus Muller, 1857( Oligochaeta: Glossoscolecidae ) Inoculation on
Litter Weight Loss and Soil Nitrogen in Mesocosms in the Peruvian Amazon. Caribbean Journal of Science 42, 410-418.

Teng, S.K., Aziz, N.A.A., Mustafa, M., Laboh, R., Ismail, I.S., Devi, S., 2016. Potential role of endogeic earthworm Pontoscolex corethrurus in remediating banana blood disease: a preliminary observation. European Journal of Plant Pathology 145, 321-330. http://dx.doi.org/10.1007/s10658-015-0846-x.

Teng, S.K., Azwady, A.A.N., Anang, N., Mustafa, M., Ismail, A., Yan, Y.W., 2013. Earthworm diversity and population density in the kaki bukit agroecosystem, perlis, peninsular Malaysia. Tropical Ecology 54, 291-299.

Tilman, D., Lehman, C., 2001. Human-caused environmental change: impacts on plant diversity and evolution. Proc. Natl. Acad. Sci. U.S.a 98, 5433-5440.

Topoliantz, S., Ponge, J.-F., Arrouays, D., Ballof, S., Lavelle, P., 2002. Effect of organic manure and the endogeic earthworm Pontoscolex corethrurus (Oligochaeta: Glossoscolecidae) on soil fertility and bean production. Biology and Fertility of Soils 36, 313-319. http://dx.doi.org/10.1007/s00374-002-0535-8.

Topoliantz, S., Ponge, J.F., Ballof, S., 2005. Manioc peel and charcoal: a potential organic amendment for sustainable soil fertility in the tropics. Biology and Fertility of Soils 41, 15-21. http://dx.doi.org/10.1007/s00374-004-0804-9.

Tripathi, G., Bhardwaj, P., 2005. Biodiversity of earthworm resources of arid environment. Journal of Environmental Biology 26, 61-71.

Tsai, C., Shen, H., Tsai, S., 2000. Occurrence of the Exotic Earthworm Pontoscolex Corethrurus (Muller) (Glossoscolecidae: Oligochaeta) in Taiwan, vol. 2. pp. 68-73.

Van Gestel, C., Weeks, J., 2004. Recommendations of the 3rd international workshop on earthworm ecotoxicology, Aarhus, Denmark, august 2001. Ecotoxicology and Environmental Safety 57, 100-105.

Vannucci, M., 1953. Biological notes: on the Glossoscolecid earthworm Pontoscolex corethrurus. Dusenia 4 (5), 287-301.

Vermeij, G.J., 1996. An agenda for invasion biology. Biological Conservation 78, 3-9.

Villenave, C., Rabary, B., Kichenin, E., Djigal, D., Blanchart, E., 2010. Earthworms and plant residues modify nematodes in tropical cropping soils (Madagascar): a mesocosm experiment. Applied and Environmental Soil Science 2010, 1-7. http://dx.doi. org $/ 10.1155 / 2010 / 323640$.

Waddington, C., 1965. Introduction to the symposium. In: Baker, H.G., Stebbins, G.L. (Eds.), The Genetics of Colonizing Species. Academic Press, New York, pp. 1-6.

Williamson, M., Fitter, A., 1996. The varying success of invaders author ( $\mathrm{s}$ ): mark williamson and alastair fitter published by: ecological Society of America stable. Ecology 77, 1661-1666. http://www.jstor.org/stable/2265769.

Wurst, S., 2010. Effects of earthworms on above and belowground herbivores. Applied Soil Ecology 45, 123-130. http://dx.doi.org/10.1016/j.apsoil.2010.04.005.

Zavala-Cruz, J., Trujillo-Capistran, F., Ortiz-Ceballos, G.C., Ortiz-ceballos, A.I., 2012 Tropical endogeic earthworm population in a pollution gradient with weathered crude oil. Environmental Sciences 7 (1), 15-26.

Zhang, H., Yang, X., Du, J., Wu, Y., 2008. Influence of soil temperature and moisture on the cocoon production and hatching of the exotic earthworm Pontoscolex corethrurus. Zoological Research 29, 305-312. http://dx.doi.org/10.3724/SP.J.1141.2008. 03305.

Zhang, M., Zou, X., Schaefer, D. a, 2010. Alteration of soil labile organic carbon by invasive earthworms (Pontoscolex corethrurus) in tropical rubber plantations. European Journal of Soil Biology 46, 74-79. http://dx.doi.org/10.1016/j.ejsobi.2009.11.004.

Zou, X., 1993. Species effects on earthworm density in tropical tree plantations in Hawaii. Biology and Fertility of Soils 15, 35-38. http://dx.doi.org/10.1007/bf00336285.

Zou, X., Gonzalez, G., 1997. Changes in earthworm density and community structure during secondary succession in abandoned tropical pastures. Soil Biology and Biochemistry 29, 627-629. http://dx.doi.org/10.1016/S0038-0717(96)00188-5.

Zou, X., Arandes-Perez, B., Capo-Ramos, D., Gutierrez-Santiago, J., Rosario-Santiago, M., 2006. Comparisons of earthworm community structure between an active pasture and an adjacent tropical wet forest in Puerto Rico. Caribean Journal of Science 42, 311-314.

Zund, P.R., Pillai-McGarry, U., McGarry, D., Bray, S.G., 1997. Repair of a compacted oxisol by the earthworm Pontoscolex corethrurus (Glossoscolecidae, Oligochaeta). Biology and Fertility of Soils 25, 202-208. http://dx.doi.org/10.1007/ s003740050304. 